\title{
Studies on the Extragonadal Estrogens
}

\author{
Saburo ONO \\ Department of Obstetrics \& Gynecology, Kobe Medical College \\ (Director : Prof. Yasuo UEDA)
}

Variation of output of urinary estrogens before and after oophorectomy or adrenalectomy, or both, in patients with uterine cancer, recurrent or metastatic breast cancer, have been observed by using modified Ittrich's chemical method of estimation. Concurrently, the following have also been investigated:

1. The effects of administration of ACTH, PMS, HCG, corticoids and synthesized gestagen (norethindrone), on the excretion of estrone, estradiol-17 $\beta$, and estriol in urine.

2. The problems of estrogen metabolism in human liver, in patients with breast cancer, after castration, right adrenalectomy and anastomosis of the left adrenal vein with renal vein, and of secretion of estrogens from the ovaries in postmenopausal women after adrenalectomy.

3. The effects of subtotal adrenalectomy against Cushing's disease on the symptoms and estrogen milieu.

The following results have been obtained:

1) It was found that there is an abrupt decrease in the output of urinary estrogens soon after oophorectomy, and that the recovery of urinary estrogen level noted after a while, and stabilized due mainly to recovered estriol value. As a result of a decrease in estradiol-estrone fractions and relative increase in estriol fraction, higher quotient of $\mathrm{ET} / \mathrm{EO}+\mathrm{ED}$ was observed after oophorectomy.

2) Marked increase in the output of urinary estrogens, particularly of estriol fraction was observed when ACTH was administered to castrated women with intact adrenals. No apparent response to the administration of gonadotropin after oophorectomy was obtained.

3) Marked decrease in the output of urinary estrogens, particularly of estriol fraction when prednisolone and dexamethasone was administered to castrated women.

4) Decrease in amount of estriol in urine when small doses of norethindrone were administered to castrated women.

Increase in the output of urinary estrogens, mostly of estrone fraction, followed by an increase in estradiol fraction when large doses of norethindrone were administered to castrated women or castrated combined with adrenalectomy.

It is assumed that this is due to extraglandular conversion of 19 norsteroids, particularly to estrone first and then estradiol-17 $\beta$. 
5) Further reduction in the output of urinary estrogens (mean value, 3.7 $\mu \mathrm{g} /$ day) have been observed and no response was seen with ACTH after oophorectomy and adrenalectomy.

6) On the other hand, a slight increase in the output of urinary estrogens has been observed when ACTH was administered to castrated women with right adrenalectomy and anastomosis of the left adrenal vein with renal vein. This is probably due to a gradual process of the estrogen molecule disintegration in human liver and an overflow-phenomenon beyond its capacity.

7) There was a maintenance of excretion of small amounts of estrogens in urine. Still secreted from the ovaries in postmenopausal women after adrenalectomy.

((pp. 678 697) 


\section{性腺外エストロゲンに就いての研究 \\ 神戸医科大学産婦人科教室（主任 植田教授）}

小野 三 郎

(昭和 38 年 5 月 2 日受付)

\section{第一章 緒 言}

Estrogen の作用を性機能に直接関与する reproductive action と，全身的な代謝機能の調節に関与する metabolic action とに大別すると, 卵巣性の estrogen は性現象の遂行に第一義的な役割を演ずる事から reproductive estrogen と呼ばれて居るが，性腺外の estrogen (extragonadal estrogen) は主として生体の 代謝機構の円滑な運営に必要な estrogen であると言う考え方から, 此れを basic or metabolic estrogen と呼んで居る。

所で副腎皮質が性腺外 estrogen の主な生成の場であろうとの考方方は Collow ${ }^{12}$ (1940)，Beall ${ }^{2)}$ (1940) 等の実験的研究以来, 可成り古くから注目されて居たが, 此の重要性が臨床内分泌学的な立場より認識され る様に成つたのは，Huggins，Bergenstal）（1951）の末期乳癌に対する副腎外科の輝かしい治療成績以後の事 であり, 此の報告以来, 性腺外 estrogen の動態を解明する事が要望されて来た, しかし, 当時は此の方面 の研究に大きな障碍が残されて居た，其れは測定技術の問題であつた。言う迄もなく，微量の estrogen を 正確に測定するには，高度の抽出率と chromogen の除去化を具備して居なければならない.しかるに，近 年に至つて， steroids 測定技術の進歩の結果，いくつかの此の様な条件をほぼ満足する方法が報ぜられる様 に成つた。 そてで，著者は此等の中，Itrich ${ }^{4}$ 〜 ) の測定法を取りあげ，其の精製，分劃操作を一部改変し可 成り正確性を期する事か河能であると考えられたので，以下，本測定法に依つて性腺外 estrogen の諸問題 に就いて検討を加える事とした。

\section{第二章 測定方法並びに其の検討}

著者の行つた測定方法は Ittrich が報告した測定法（1958）を基とし，此れに Salokangas，Bulbrook が榆 討した Purification Step (1960) を加味した変法である. 此の測定法の大要を Table 1，2，3 亿示す.

第一項

1) 加水分解：24時間尿（1 日尿量の少ないもの, 即ち, 尿不純物の濃度が高いもの程， estrogen の回収率 が低下するので，1.5l以下の場合は水を加えて $1.5 l$ とる）から $100 \mathrm{ml}$ の尿を採取し，此れに $15 \mathrm{ml} の$ conc. HCl を加え沸騰中の water-bath で $100^{\circ} \mathrm{C} 1$ 時間加熱水解した.

2) 抽出及び精製 : 水解が完了すると, 此れを冷却した後, ethyl ether $50 \mathrm{ml}$ を用いて分液ロートで激し く振蕰し 2 回抽出した. 次いで, 此の ether 層を $40 \mathrm{ml}$ の carbonate buffer solution ( $\mathrm{pH} 10.5,8 \%$ Na$\mathrm{HCO}_{3}$ 溶液に20\% NaOH 溶液を加えPH10.5亿調製する）と $30 \mathrm{ml}$ の $8 \% \mathrm{NaHCO}_{3}$ 溶液で各々洗滌した。 最後に蒸溜水 $20 \mathrm{ml}$ で洗い，水首を除き，上層の ether 譄を蒸溜乾固させる，以上の洗涤操作は主に acid fraction 及び不純物の除去を目的としたものである. 次いで phenol fraction の抽出操作に移るが，上記の

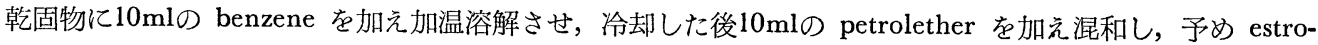
gen を充分に溶解させて置く．此の溶液を分液ロートに移し，此のものに $1 \% \mathrm{NaOH}$ 溶液 $9 \mathrm{ml}$ 加え，充 分振晹した後, 下首の水溶液首を分離抽出し, 此の操作を 2 回繰り返えす。此の様にアルカリ溶液に依つて 有機溶媒から estrogen を抽出する際に Brown” は estriol を予め水で抽出し， estrone-estradiol 分劃を分 離して居るが，著者は此の段階で 2 部分に分ける事なく，最後の chromatography で 3 分劃に分け，操作 の煩雑さを避ける事とした．次いで，此の $1 \% \mathrm{NaOH}$ 抽出液に9grの $\mathrm{Na}_{2} \mathrm{CO}_{3} \cdot 10 \mathrm{H}_{2} \mathrm{O}$ を加え，充分振灟溶 解した後, 此のものに $2 \mathrm{ml}$ conc. HCl を添加し, 再び20mlの ethylether を加えて振蕰すると estrogen 
Table 1. Extraction procedure of urinary estrogens

$100 \mathrm{ml}$. of $24 \mathrm{hr}$. urine

$15 \mathrm{ml}$. of conc. $\mathrm{HCl}$ added, heated in water-bath at $100^{\circ} \mathrm{C}$ for 1 hour the specimens filtrated

the urine extracted twice with $50 \mathrm{ml}$. of ethylether

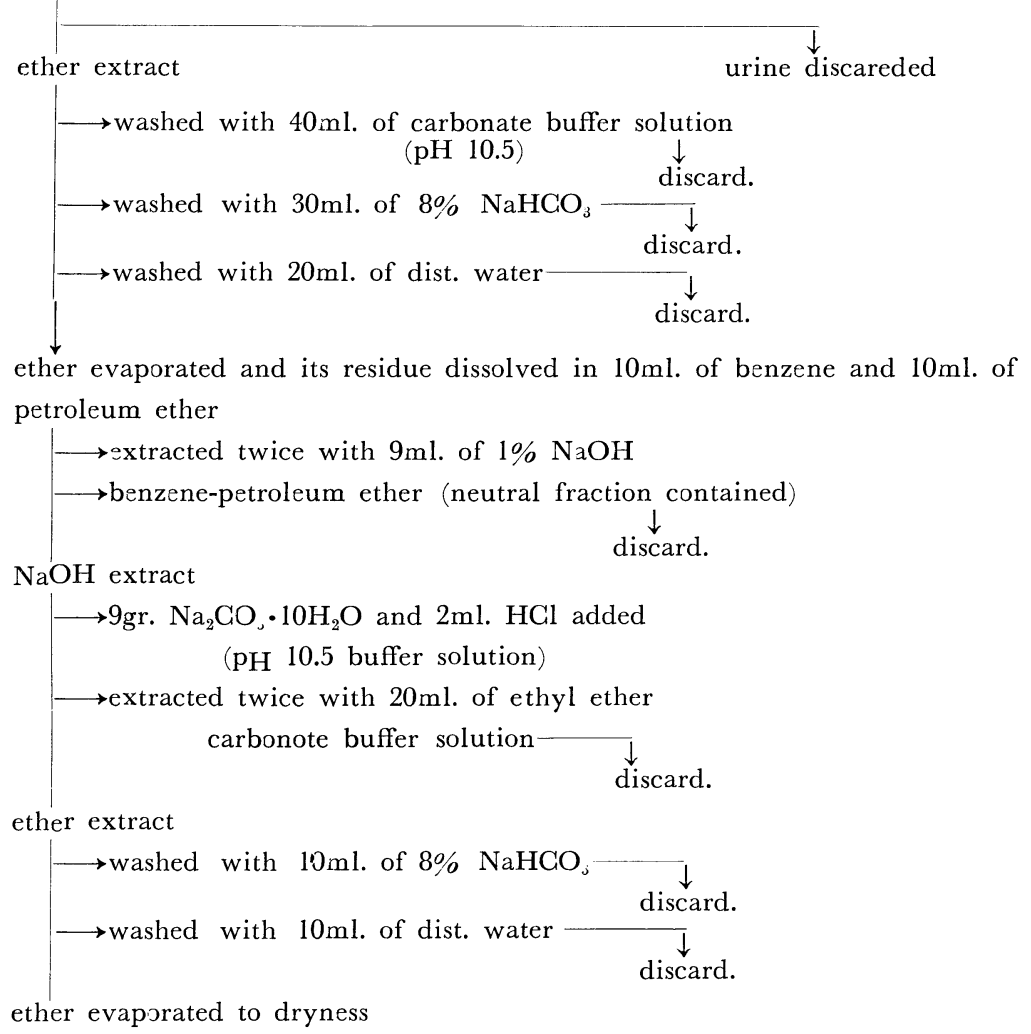

Table 2. Procedure of chromatographic separation

Adsorbent : partially inactivated Alumina mesh $200 \sim 300$

( $7 \mathrm{ml}$. dist. water added to $100 \mathrm{gr}$. activated $\mathrm{Al}_{2} \mathrm{O}_{3}$ )

Eluant : benzene-ethanol

Flowrate : 15 20 drops/min.

Temperature : room temp.

1. Adsorption to $3 \mathrm{gr}$. part. inact. alumina

2. Elution
a Eluant
5rnl. $\mathrm{CCl}_{4}$, $5 \mathrm{ml}$. benzene

$9 \mathrm{ml} .0 .8 \%$ ethanol in benzene

other steroids, chromogen cotained

b Eluant $\quad 12 \mathrm{ml} .0 .8 \%$ ethanol in benzene estrone eluted

c Eluant $\quad 10 \mathrm{ml} .3 \%$ ethanol in benzene estradiol eluted

d Eluant $12 \mathrm{ml} .30 \%$ ethanol in benzene estriol eluted

3. Solvent evaporated to dryness 
Table 3. Procedure of coloration (for Fluorescence)

$1 \mathrm{ml}$. Hydrochinone- $\mathrm{H}_{2} \mathrm{SO}_{4}$ reagent added to the specimen $\left(\begin{array}{ccc}\text { optimal concentration } & 52 \mathrm{vol} . \% \mathrm{H}_{2} \mathrm{SO}_{4} \text { for estrone } \\ & \text { estradiol } \\ & 68 \mathrm{vol} \% \mathrm{H}_{2} \mathrm{SO}_{4} \text { for estriol }\end{array}\right)$

for $40 \mathrm{~min}$. heated at $100^{\circ} \mathrm{C}$ in water-bath

for $2 \mathrm{~min}$. cooled immediately in ice-water $1.5 \mathrm{ml}$ dist. water added, after cooling well shaken, cooled again for $3 \mathrm{~min}$.

4.5ml. p-Nitrophenol-Solution added $2 \%$

(Solution of tetrachloroethane containing P-Nitrophenol)

a major step for the purifiication of urinary extracts is affected after the kober reaction has been carried out, using a specific extraction of the kober colours with P-NitrophenolSlution

this P-Nitrophenol-Solution underlaid

for $3 \mathrm{~min}$. cooled in ice-water

for 30 sec. strongly shaken

for $2 \mathrm{~min}$. centrifugal separation, then its upper phase discarded.

Kober colour selectively extracted with tetrachloroethane containing P-Nitrophenol (2\%)

and transmit to lower, organic phase this kept in the dark ice-box until measurement fluorimetry : primary $546 \mathrm{~m} \mu$ green mercury line secondary $562 \mathrm{~m} \mu$ (interferencefilter excludes wave length shorter than $560 \mathrm{~m} \mu$ or 576 to $578 \mathrm{~m} \mu$ )

は ether 層に移行するので，下層の水液層を除去し，再び此れから $20 \mathrm{ml}$ ethylether で抽出する，以上の 操作で neutral fraction と著しく多量の不純物を除去する事が出来る. 次に上記の両 ether 層を合せ, 此 れに $10 \mathrm{ml}$ の $8 \% \mathrm{NaHCO}_{3}$ 溶液を加え振盪した後, 下層を除き, $10 \mathrm{ml}$ 蒸溜水で洗桬する. 此の ether 層は充分脱水した後蒸溜乾固する.

3) 分劃 : 内径 $10 \mathrm{~mm}$, 長さ $30 \mathrm{~cm}$, 上端に約 $30 \mathrm{ml}$ の貯液部を備え, 下端の点滴口の内径が $1 \mathrm{~mm}$ であるク口 マト管を使用した，使用に当つて，クロマト管の下端に綿栓を施し，予め estrogen (estrone, estradiol-17 $\beta$, estriol）の各分劃が適当な溶出域を得る様に活性度を標定したAlumina（和光純薬株式会社製活性アルミナ mesh 200〜300 に蒸溜水を $7 \mathrm{gr} \%$ 割合に均一に加え活性を調節したもの） $3 \mathrm{gr}$ をクロマト管に入れ，此 れを四塩化炭素で満した後，アルミナ柱の上面に石英砂を $5 \mathrm{~mm}$ の厚さに重ね上面を安定にした.

次いで，クロマト管中の四塩化炭素を滴下させ，四塩化炭素の液面がアルミナの上面約 $5 \mathrm{~mm}$ 所に下降 した時に, estrogen 抽出乾固物を $2 \mathrm{ml}$ benzene に加温溶解し, 此れに $4 \mathrm{ml}$ 四塩化炭素を加え混和し た検体溶液を室温に保つた後にアルミナ柱に重畳し, 吸着させ, 此れを $5 \mathrm{ml}$ の四塩化炭素と $5 \mathrm{ml}$ benzene で 1 回宛洗つた後, 下記の如く溶出を始め分劃した.

(1) $9 \mathrm{ml} 0.8 \%$ ethanol 加 benzene 溶液で estrogen 以外の steroids や不純物を溶出.

(2) $12 \mathrm{ml} の 0.8 \%$ ethanol 加 benzene 溶液で estrone を溶出.

(3) $10 \mathrm{ml} の 3 \%$ ethanol 加 benzene 溶液で estradiol- $17 \beta$ を溶出.

(4) $12 \mathrm{ml}$ の $30 \%$ ethanol 加 benzene 溶液で estriol を溶出.

この際, 溶出液の温度は室温, その他溶出速度等の条件は一定とした. 又, 予め検体容器を溶出溶媒で良 く洗ひ，特に難溶な estriol はクロマトに充分移行させる事が大切である，此の様にして，溶出を終れば各 々の溶媒を蒸発乾固し比色供する.

4) 螢光発色 : 分劃した各検体に $1 \mathrm{ml}$ hydrochinone- $\mathrm{H}_{2} \mathrm{SO}_{4}$ 試薬を加え, 此れを40分間, 沸騰中のwaterbath で加熱し螢光発色を行う. 加熱が終れば検体を直ちに 3 分間氷冷し，其の各々に蒸溜水 $1.4 \mathrm{ml}$ 加え， 3 分間更に氷冷した後振盪混和する. 此れを再び氷冷した後 $4.5 \mathrm{ml}$ の P-Nitrophenol-solution (100ml の四 塩化エタンに $2 \mathrm{gr} の$ p-nitrophenol 及び $1 \mathrm{ml}$ ethanol を含む溶液）を加え 3 分間氷冷した後，検体容器 を密栓し，30秒間激しく振盪し，次いで，2 分間遠心分離 (1500回転/分) すると，検体は上下の 2 層に分 離される. 此の操作は kober 反応に依つて生じた抽出物中の不純物を除去する目的で行はれるのであり, 
此れが操作中最も特異且つ有力な purificaton step である. Kober substance は下層の organic phase に 選択的に抽出されて居り, 螢光発色の際, 強酸との加熱によつて生ずる chromogen は上首の水溶液相に留 まつて居る，そてで，上首をピペットで吸引裹捨し，Kober substance が移行した下層 (organic phase)を 検体として測定まで暗氷室中に保存する。

5) 測定 : 検体と同一条件で螢光発色させた standard の螢光值を100とした時の読みに就き，予め estrone，

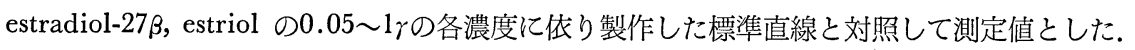

測 定 器 日立分光光度計

1 次 filter : $546 \mathrm{~m} \mu$ green mercury line

2 次 filter : $562 \mathrm{~m} \mu$

(Interference filter : $560 \mathrm{~m} \mu$ 以下の短波長及び 577 〜79m $\mu$ の波長を除去)

光源 : mercury source

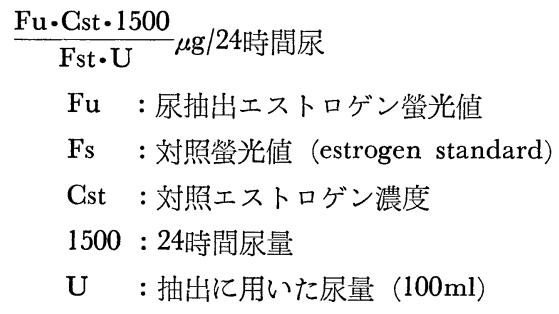

6) 本法の回収率 : Estrogen 含有量を予め測定した卵巣, 副腎剔出婦人尿 $100 \mathrm{ml}$ を酸加熱水解し, 此れそ estrone, estradiol-17 $\beta$, estriol を各々 $2 \mu \mathrm{g}$ 宛添加し, 抽出, 精製, 分劃の全操作を行い測定值を求め, 此の值 より平均回収率と精度を求めた. 其の結果は下図の如くである.

\begin{tabular}{c|c|c|c|c}
\hline \hline 測定回数 & 添加 $\mathrm{E}$ 量 & $\mathrm{E} \mathrm{O}$ & $\mathrm{E} \mathrm{D}$ & $\mathrm{E} \mathrm{T}$ \\
\hline \hline 10 & $2 \mu \mathrm{g}$ & $76 \pm 4.5$ & $72 \pm 5.7$ & $75 \pm 6.1$ \\
\hline & \multicolumn{2}{|c|}{ 平均回収率 $\%: \pm$ 標準偏差 } \\
\hline
\end{tabular}

又, Chromatography の平均回収率は下表の如くである.

\begin{tabular}{|c|c|c|c|c|c|}
\hline $2 \mu \mathrm{g}$ & EO & 94 & $\bigcirc$ & O & \multirow{3}{*}{$\%$} \\
\hline " & E D & 0 & 92 & 0 & \\
\hline " & $\mathrm{ET}$ & 0 & 0 & 97 & \\
\hline \multicolumn{2}{|c|}{ 溶出溶媒 } & $0.8 \% \mathrm{E}$. 加. B & $3 \% \mathrm{E}$. 加 B . & $30 \% \mathrm{E}$. 加 B . & \\
\hline
\end{tabular}

7) 本法の測定域 : $0.1 \mu \mathrm{g}$ の estrogen を尿 $100 \mathrm{ml}$ (estrogen 含有量か溉知の水解尿) に添加して回収試 験を 5 回行つた結果, 其の測定誤差は土 $25 \%$ 以下で, 標準偏差は \pm 0.08 と言う成績を得た。従つて，0.1 $\mu \mathrm{g}$ 以上の estrogen を含有する場合, 本法は測定可能である.

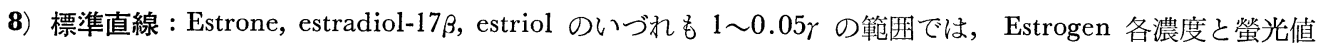
との間に直線的関係を示した。

( $\mathrm{P}<0.001$ 亿て直線的回帰を取る)

第二項 小括

estrogen の化学定量法は加水分解，抽出，精製操作，chromogen 除去法等いくつかの点で尚問題か残さ 第39巻 第 8 号 
れて居り，完全と言光る方法は見出されていない，そてで，以下，著者の用いた方法を中心として，此等の 問題点に就き遂次言及する事とする.

先づ水解法に就いては, 人尿中の estrogen は既知のグルクロン酸や硫酸の他, 恐らく尚未知の酸とも結 合し, 水溶性の conjugated estrogen として排泄されると考えられて居るので, 現行の estrogenconjugate の水解至適条件が或る程度不正確，不完全である事は当然の事と言え，又， estrogen (3 分劃) の glucuronide が化学的に合成出来ないので，水解操作に依る真の estrogen 回収率を測る事が不可能である事も其の 一因と成つて居る. 所で, 著者が routine procedure として用いた水解法は $15 \mathrm{vol}$ \% conc. HCl で 1 時 間加熱水解するが，此の方法は酸加水分解法としては現在最も普遍的であり， Marrian et al (1933) の系 統的な研究に依つても, 本法が臨床応用の範囲内では適当であるとされて居る. 且し, 此の方法も臨床的に 意味の大きい, 即ち, 生物学的作用の高い 3 classic estrogen の抽出時にのみ適当であり, 最近見出された 一連の very sensitive ketolic estrogen の場合は, 此等か酸加熱水解に依つて分解され易いので, 不適当で あるとされて居る．今日迄に人体から約18種の天然 estrogen が分離同定され，人の尿中に既に12の新しい estrogen が代謝産物として報ぜられて居るが，此等の多くは何れも生物学的活性が弱く, 其の生物学的特性 も不明のものが多い. 更に, 此等の中, 16 $\alpha, \beta$,-hydroxyestrone, 16-keto-17 $\beta$-estradiol, 18-hydroxyestrone の如きはアルカリに非常に sensitive である事から，従来のアルカリ抽出法では抽出が不可能であるとされ， 又 2-methoxy-estrone は有機溶媒からアルカリに容易に移行しないので定量的に抽出出来ない. 又, slaunwhite (1953) の研究に依れば, 2-methoxyestrone, 16-ketoestrone, 17-desoxoestrone 等の新しい estrogen は何れも硫酸試薬と殆んど反応せず，螢光を発しないと報告されて居る，此の様に，此等の新しい estrogen の定量的抽出法や螢光特性は今後検討されるべきである.

次に抽出，精製過程に就いてであるが，Cohen and Marrian ${ }^{11)}$ (1934) 酸加熱水解した妊婦尿から estriol と estrone, estradiol の抽出, 精製方法を発表して以来, 此れが今日に於ても, 依然, 抽出精製操作の基本 となつて居る。著者の方法でも加水分解尿は ether で抽出され，従つて，此の抽出物は ether soluble steroids や他の有機物を包含して居るので, 此のものを PH10.5 の $\mathrm{Na}_{4} \mathrm{CO}_{3}$ buffer solution, 8\% $\mathrm{NaHCO}_{3}$ Solution で洗桬して, 其の acid fraction と不純物を除去した。此の原理は弱いアルカリ溶液から estrogen を ether で定量的に抽出出来るが，もし此のアルカリ溶液が PH10〜10.5であると， estrogen に伴う不純 物の多くはアルカリ相に留るので，精製操作とも成り得る事が Engel 等依つて示されて居る事にある.

又, Brown の研究に依ると ether とアルカリの間の estrogen 分配係数は PH 值より ion 強度に依存する 事が確められて居り, PH10.5の carbonate buffer solution から estrogen を定量的に抽出し, 極めて著し い精製効果をあげ得るとされて居る。次に，アルカリ溶液に依る phenolic fraction の抽出は estrogen が ether 層からアルカリ溶液に依つて定量的に直接抽出されないので, ether を一且蒸発乾固した後に, benzene-petrolether に溶解させ， $1 \% \mathrm{NaOH}$ 溶液をもつて estrogen を抽出し, neutral fraction を分離し, 再度, 此のものを carbonate buffer solution を用いて精製した.

次に，分劃法として行つた Alumina column chromatography は Heard et al ${ }^{2)}$ (1941) Stimmel ${ }^{13}$ ) (1946) 亿依つて estrogen の分劃, 定量に用いられたものであるが, 本法の欠点は市販のアルミナの性質に 依つて吸着能に可成りの相異が㴓められる事とアルミナの不充分な調製に依つて分劃が不完全且つ不正確に 成り勝ちな事であろう。従つて，満足すべき分劃，回収を得るには，アルえナの活性を非常に注意深く正確 に標定する必要がある。此の点, Brockmann 標定は分劃に用うるにはやや不正確にすぎるららみがあり, 標定するには必ず estrogen をもつて直接確めねばならない. Stimmel の原法は回収率が幾分低く，特に estriol の回収率が低い. そこで，Brawnはアルミナ柱で分劃の際に蒝溜水を用いて其の partial inactivation を行つて居るが，著者は Ittrich の方法に従い，前記の如く標定したアルミナ柱で分劃し，一応満足す べき結果を得た。

次に螢光発色に就いてであるが, 従来の抽出, 精製, 分劃法に依ると, いづれも, 尿抽出物中に estrogen 以外の不純物が含まれて居り，此れが Kober 反応時に nonspecific brown colour として千渉し，測定の 
障得と成つて居た，従つて，比較的 estrogen 量の多い抽出物に於いてのみ正確な測定が可能であり, 微量 の estrogen を測定するには，此の nonspecific brown colour substance を可及的分離する必要がある. 此の目的で従来から種々の光学的補正式や測定後の加熱, アセトン添加, 或いは過酸化水素水添加に依る消 去法が試みられて居たが，此等の方法は不純物が多くしかも estrogen の微量な場合は効果が甚だ不充分で あつた。此の点に注目した Ittrich は kober 反応後に生ずる colour compound p-nitrophenolchloroform 溶液で選択的に抽出し, 不純物の大部分を除去する事に成功した。 螢光測定法でも尿抽出物を強酸で 処理すると kober 反応の場合と同様な障碍が chromogen に依つて惹起されるが，此の選択的抽出に依つ て chromogen の大部分が除去される結果, chromogen に由来する励起光及び螢光の減弱は著るしく減少 するので estrogen 本来の螢光は強められる結果となる。のみならず fluorescence spectrum の長波長側え の移行は, energy の高い励起光（短波長）に依つて励起される雑螢光を殆んど生ぜしめないので，此れが chromogen の除去とあいまつて雑螢光を著るしく弱めて居る.ささて, 此の様な選択的抽出に使用される 溶媒は前記の P-Nitrophenol-chloroform 溶液の他, その後 Ittrich や Salokangas and Bulbrook 等に依り 検討が加えられ， $\mathrm{CHBr}_{2}-\mathrm{CHBr}_{2}$ や $\mathrm{CHCl}_{-}-\mathrm{CHCl}_{2}$ か挙げられて居る。 そして，此等の溶液は螢光の stability, specificity 及び sensitivity の点で chloroform より更にすぐれ, 特に fluorescent compound の安 定度は著しく上昇すると言う。

又, estrogen の螢光定量法と比色法を比較すると, 前者は後著の10乃至100倍の感度を有するものである が, 其の反面, 螢光の不安定性, 不純螢光及び此れに対する簡便な補正法の無かつた所から, 従来, 常に其 の信頼度が危惧されて来た。しかし，上記の著者の検討した成績，即ち回収率 $72 \sim 76 \%$, 其の測定下界は 0.1 u で, 其の誤差がさ $25 \%$ を越光ないと言う成績が示す通り, 允分な抽出, 精製操作を行い, 次いで螢光 発色後に specific colour compound の選択的抽出を行い, 此れに依つて chromogen を除去し, 低エネル ギ一励起に依る不純螢光の減弱, specific fluorescence の增強や安定化を計るならば, 臨床内分泌の診断上 ほぼ信頼するに足る成績を螢光測定法化依つて得る事が可能と言えるようである。

\section{第三章 臨 床 成 績}

\section{第一項 正常月経周期婦人の場合}

成熟锓人 2 名に就いて, 数周期に互つて基礎体温を測定し二相性である事を磪めた後, 1 月経周期間隔日 に尿中 estrogen 值の測定を行い, 其の推移を観察し, 以後の実験成績の刘照とした.

測定成績は, Fig. 1 亿示す通り, 各例共, 月経周期の前 $1 / 4$ の時期では月経周期を通じ最も低值を示して居 るが，第 7 周日頃より増量し始め第13乃至14周日附近で急速な上昇を示して居る。しかも， BBT の上昇と 同時に estrogen 值は比較的急速に下降するので，第14周日頃を最高とする一つの鋭い peak を排卵期に一 致して作るととになる. 其の後も estrogen 值は引き続き增殖期前半より高い值を保持し, 殊に第20周日よ り第26周日頃にかけて, 即ち黄体の開花期に一致して緩かに上昇し, 高值を維持し月経直前になつて再び急 速に下降するので，黄体期にも一つの鈍な peak が形成されて居る.

次に, 此の周期的変動を 3 分劃に分け観察すると, 各分劃はほぼ平行して增減して居り, ovulation peak を除き，其の平均分劃比 $(\mathrm{ET} / \mathrm{EO}+\mathrm{ED})$ は1.1であつた.

\section{第二項 去勢婦人の場合}

手術的に卵巣を剔出し, 術後の一般状態が安定し且つ異常所見（殊に肝機能）を認めない症例の尿中 estrogen を測定した. 先づ子宮頸癌手術患者に就いて, 術後の尿中 estrogen を遂日的に測定する一方, 手術直 後より術後 1 年までの間で種々の日数を経過した去勢婦人を約 50 例選び合計 63 回の測定を行つて，去勢後の 尿中 estrogen 值の時間的変動を観察した。測定成績は, Fig. 2 亿示す如くで, 去勢直後の尿中 total estrogen 值は急速に減少したが，其の後，やや増加し始め，術後20乃至 30 日頃迄に，其の值は術前値の約 $1 / 2$ 程度ま で恢復する傾向が認められた，以後の推移は大体，此の level を維持して居るが，其の間の estrogen 3 分 劃別の変化を見ると, estriol 值のみ恢復を示し, estradiol, estrone は一且減少した後さしたる変化なく低 
值を保つて居る。尚，閉経期婦人に於いても卵巣剔出後の尿中 estrogen 值はFig. $2^{\prime}$ に示す通りやや減少し ているが，その減少の程度は有経婦人の場合に比へて遙かに軽度である。 また，尿中 estrogen の平均分劃 比 $(\mathrm{ET} / \mathrm{EO}+\mathrm{ED})$ を比較すると，有経婦人の場合は術前值は $1.1 ，$ 術後の值は1.9で，閉経期婦人の場合は 術前值は1.5, 術後の值は2.1を示した。

Fig.1. Estrogen outputs in urine of normal, menstruating women

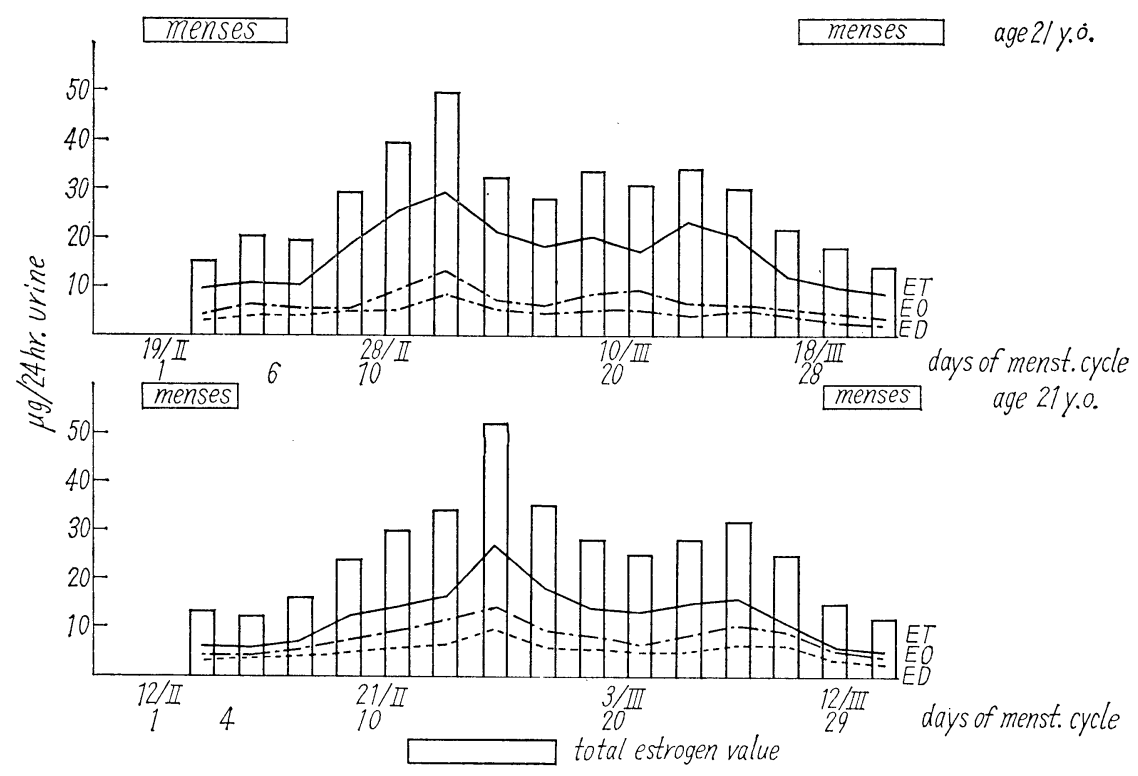

Fig. 2. Effect of oophorectomy on levels of urinary estrogen

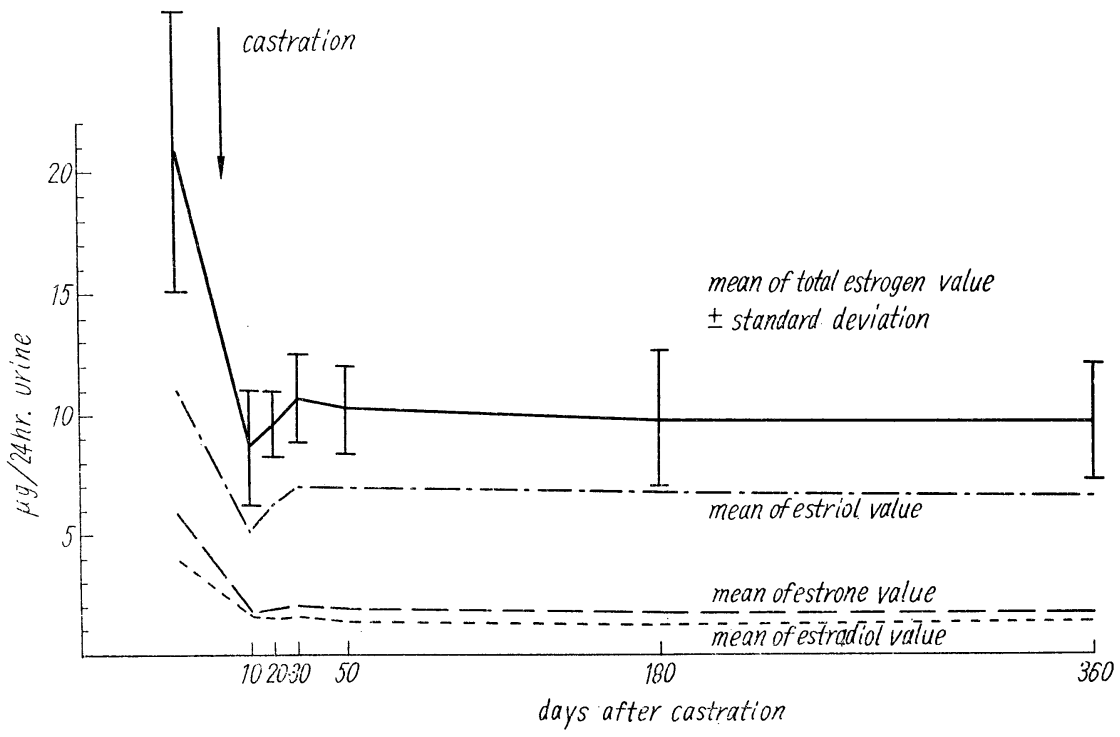


Fig. 2' Effect of oophorectomy on levels of urinary estrogens

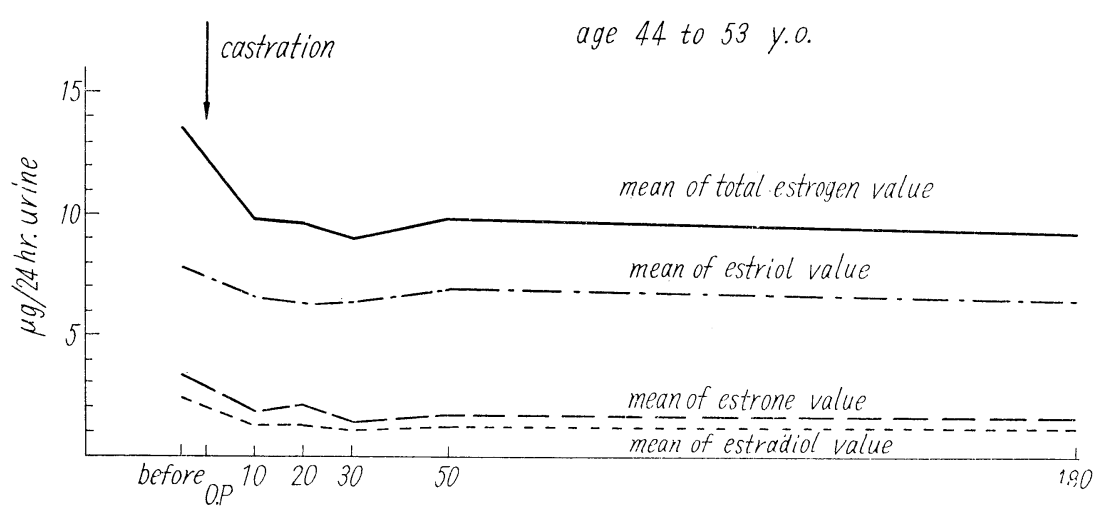

\section{第三項 種々の hormone の性腺外 estrogen の分泌に及ぼす影響}

Extragonadal estrogen の分泌を control する上位刺㦸 hormone, 或いはその他の steroid hormone と の関連を検討する目的で，去勢婦人に gonadotropin (serum gonadotropin, chorionic gonadotropin), ACTH, corticoids, 19-norsteroid 等を投与して, 尿中 estrogen の変動を観察した.

\section{1) PMS 投与の場合 :}

4 例の去勢婦人に FSH 作用の強い PMS (Anteron, Serotropin) を 1 日1000 2000単位，2 日間連続投 与した. 其の成績はFig. 3 に示す様に, 連続 5 日間の測定結果は, 全例, 投与前, 投与中，投与後を通じ特 記すべき変動を示さなかつた。

\section{2) HCG 投与の場合}

3 例の去勢婦人にLH作用の強い HCG (Primogonyl, Gonatropin) を 1 日2000単位，3 日間連続投与し た. 其の成績は，Fig. 4 亿示す様に，此の場合に於いても 2 例に estrogen 值の僅かな増加を見たが，有意

Fig. 3 Effect on PMS administration on levels of urinary estrogens after castration

PMS 1000 2000i.u./day $\times 2$ i.m.

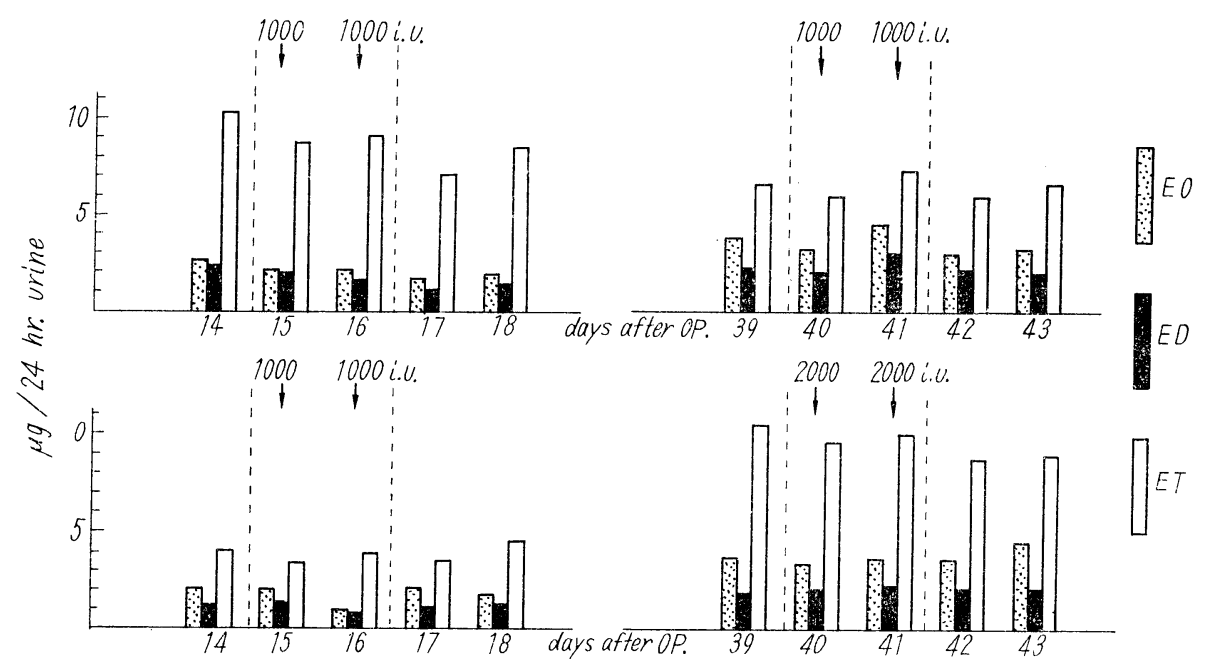


Fig. 4 Effect of HCG administration on levels of urinary estrogens after castration HCG 2000i.u./day $\times 3$ i.m.

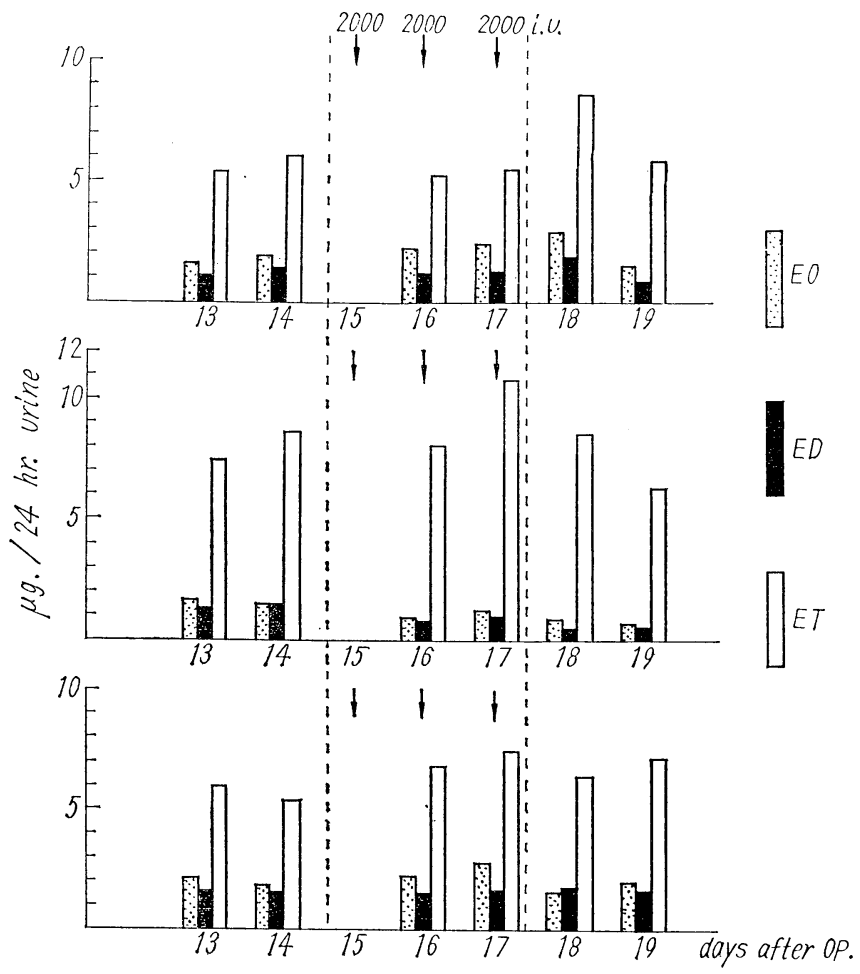

の増加とは思はれなかつた。

\section{3) ACTH 投与の場合}

去勢婦人 6 例に ACTH-Z を 4 日間に40単位（投与第 1 日目 $20 \mathrm{i} . u ，$ 第 2 日目 10i.u，第 $3 \sim 4$ 日目 5 i.u ) 投 与して，尿中 estrogen 值の動きを観察した。其の成績はFig. 5, 6亿夫々示す様に，此の場合は有意に增加 した。即ち，AGTH 投与開始直後より estrogen 值は上昇し始め，投与第 4 日目に最高値を示し，投与終 了後，第5〜7日目にほぼ投与前の值にまで下降した。此の様に ACTH に対する性腺外 estrogen の反応は 極めて速かである. 次に, 此れを 3 分劃に就いて検討すると, estriol の增加が其の大部分を占めてをり, estrone, estradiol の增加は軽度にすぎないが， estriol より速かに增加して居る. 此の6 例の測定成績を集 約すれば投与中の total estrogen 值の增加の平均91\%は estriol の夫れで占められて居る.

\section{4) Corticoids 投与の場合}

去勢婦人 2 例宛に夫々 prednisolone $(30 \mathrm{mg} /$ 日 ) と dexamethasone $(0.5 \sim 1.5 \mathrm{mg} /$ 日）を 5 日間連続投与 し，尿中 estrogen 值を測定した．測定成績はFig. 7 亿示す通り，尿中 estrogen 值は夫々の常用量で有意 亿減少して居る。即ち，Prednisolone 投与例では投与を開始した日より，漸次尿中 estrogen が減少し，一 方 dexamethasone 投与例では其の減少は前著よりより速かであつた，そして投与終了後第1〜2日目頃では， 両者共, 僅か心恢復の傾向を示して居る.

次に，此を 3 分劃に分け観察して見ると， estriol 值の減少が最も著しく，此れに対し estrone, estradiol 值の減少は軽度であつた。

5) norethindrone 投与の場合 
Fig. 5. Effect of ACTH administration on levels of urinary estrogens after castration ACTH-Z 40i.u. over a 4-dayperiod i.m.

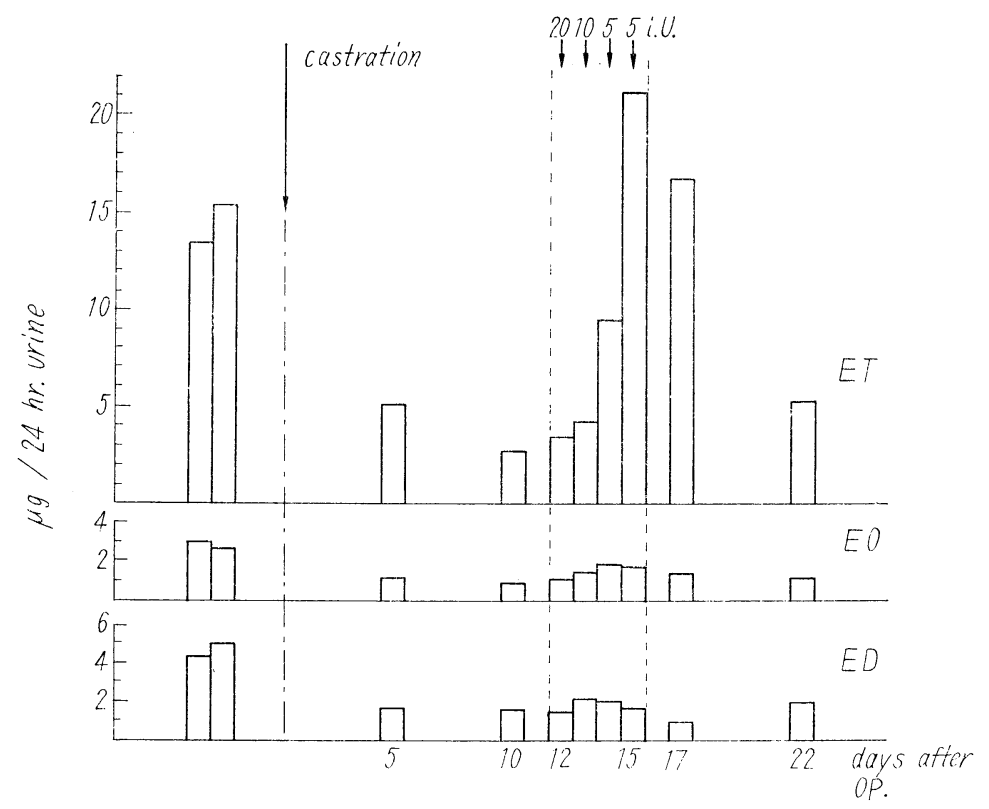

Fig.6. Effect of ACTH administration on levels of urinary estrogens after castration ACTH-Z 40i.u. over a 4-day period i.m.

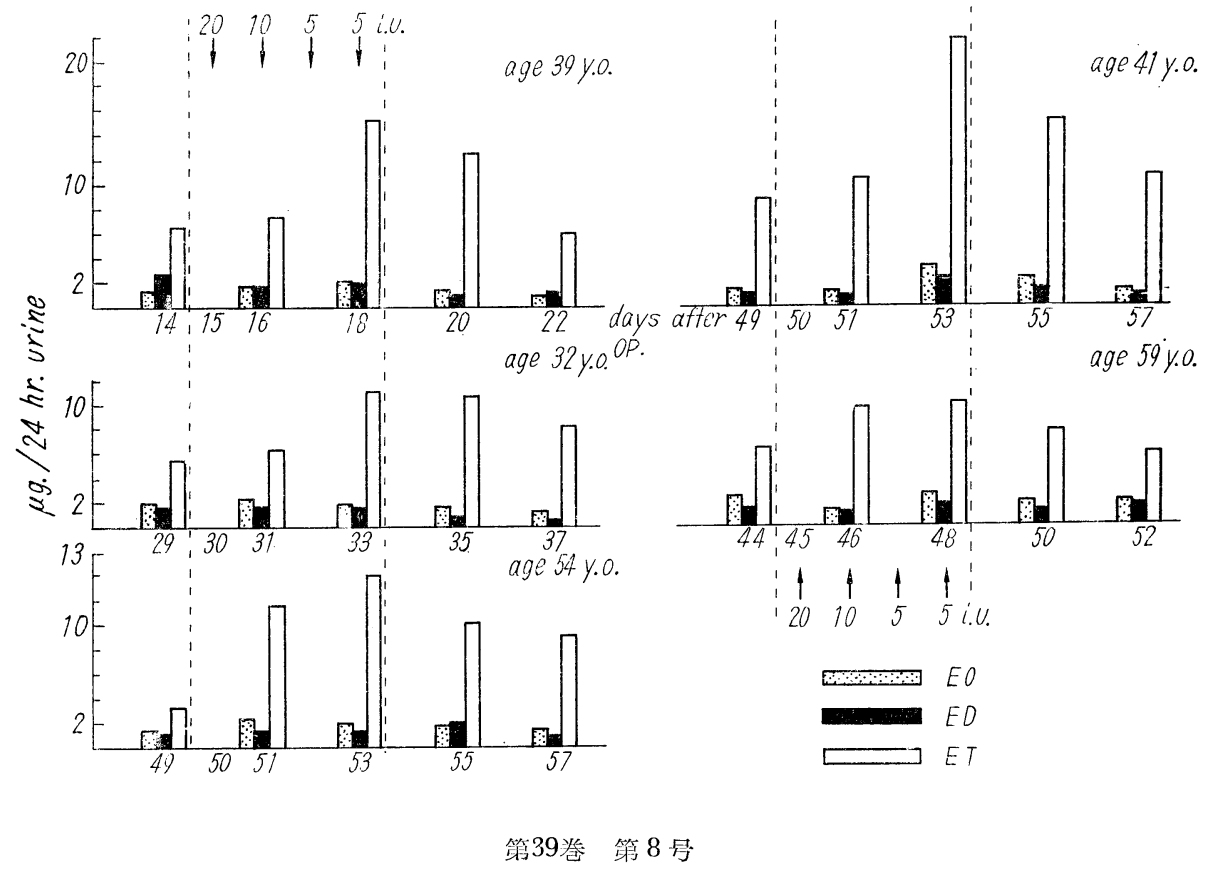


去勢婦人に norethindrone を 1 日 $5 \mathrm{mg}, 10 \mathrm{mg}, 20 \mathrm{mg}$ 宛, 夫々 14 日間連続投与した所， 5 万至 $10 \mathrm{mg}$ 投与 例では軽微乍ら total estrogen 值の減少, 殊に estriol 值の減少傾向が認められた（Fig. 8). しかし，10 $\mathrm{mg}$ 投与の一部と $20 \mathrm{mg}$ 投与例では, total estrogen 值が増加し, 殊に estrone と estradiol 值に増加傾向を 認めた．そこで，投与量を増して，1 日50mg 2 日間連続投与した所，尿中 estrogen 值は著しく増加し， 3 分劃の中でも estrone 值が最も著るしく，次いで， estradiol 值の増加が見られると言う結果を得た（Fig. 9 )。また，去勢と両側副腎剔出を同時に行つた乳癌患者に norethindroneを 1 日 $50 \mathrm{mg} ， 2$ 日間連続投与し

Fig.7. Effect of corticoids administration on levels of urinary estrogens after c astration

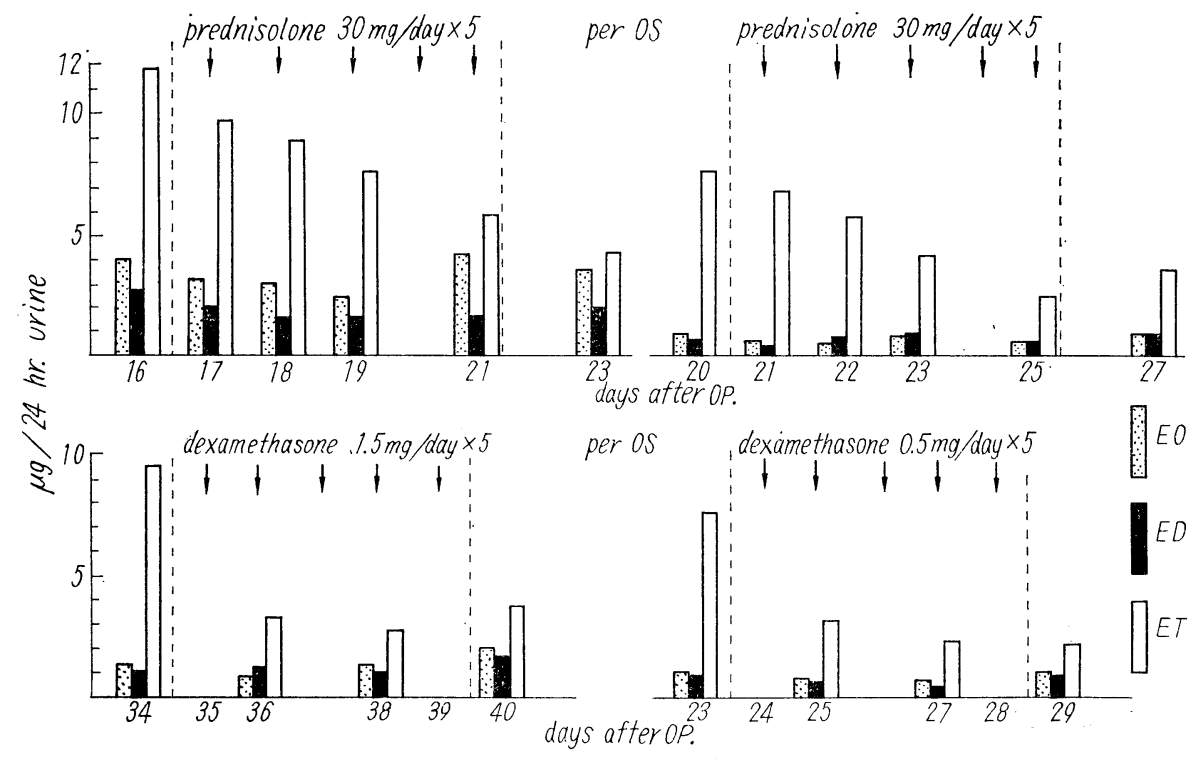

Fig.8. Effect of norethindrone administration for long time on levels of urinary estrogens after castration norethindrone $5 \sim 20 \mathrm{mg} /$ day $\times 14$ per OS
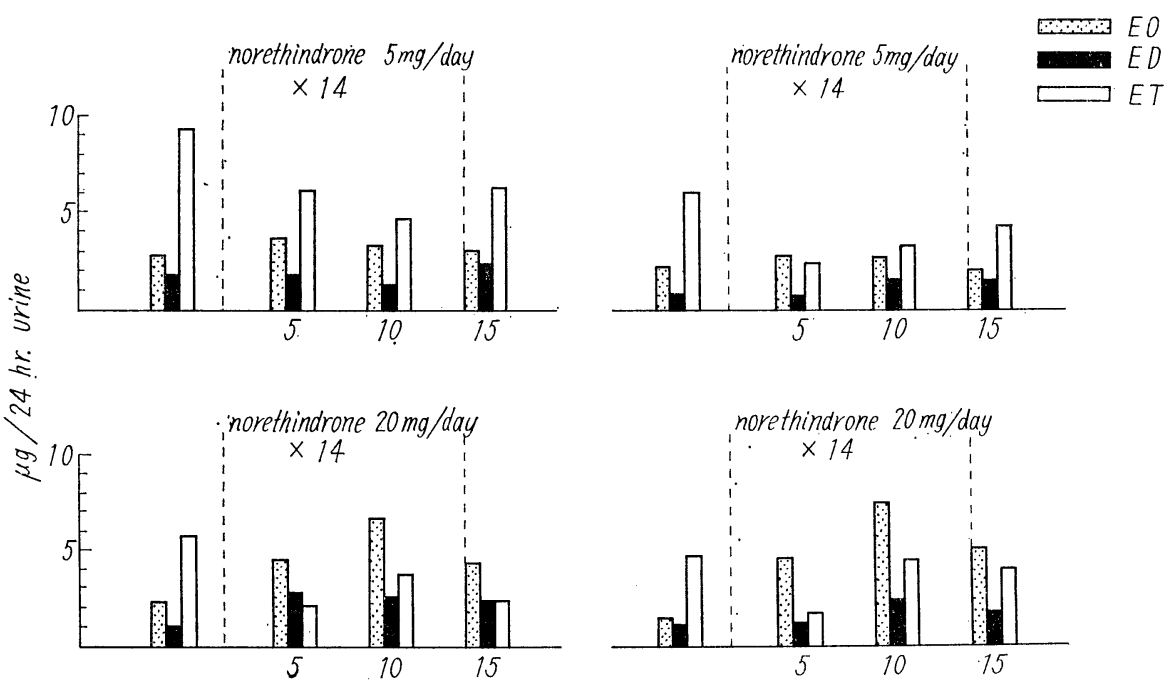

第39巻 第 8 号 
Fig.9. Effect of norethindrone administration (large dosis) on levels of urinary estrogens (over a 2-day period) norethindrone $50 \mathrm{mg} /$ day $\times 2$ per OS
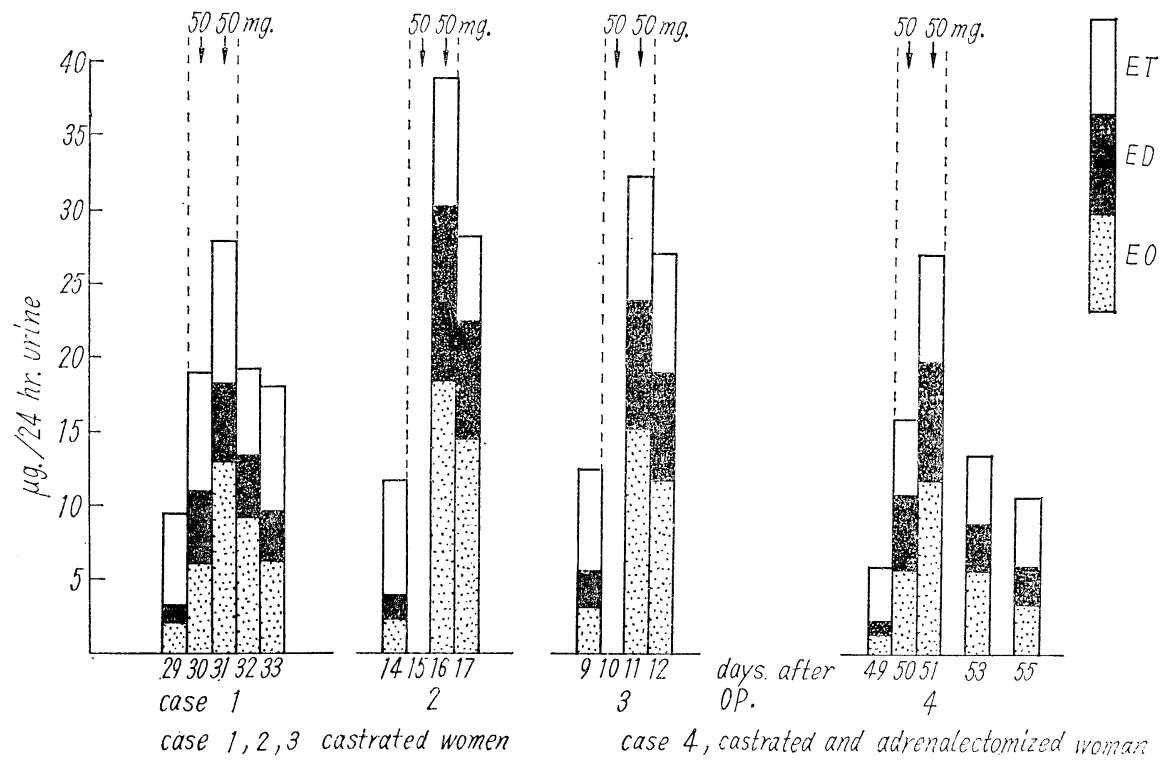

てみても，前者と同様の結果を得る事が判明した。

従つて, 以上の成績を要約すると次の様になる. 即ち, 性腺外 estrogen が ACTH, corticoids の投与に 依つて有意に変動し，しかも gonadotropin の支配下にない事は，副腎皮質が性腺外 estrogen の主要分泌 源である事を示唆して居る.一方, norethindrone 投与の増合は，少量の投与によつて estriol の減少が見 られたが，大量投与時では，反つて， estrone, estradiol の増加が見られた. 此れは, 去勢, 副腎全剔婦人 に於いても同様な結果を得る事から， norethindrone の生体内に於ける estrogen への extraglandular conversion を示すと考えられる.

\section{第四項 卵宩, 副腎剔出婦人の場合}

前述の実験成績から，extragonadal estrogen の分泌源として副腎皮質の持つ意味の甚だ大きい事か泀見わ れたので，此処では，副腎皮質が性腺外 estrogen の分泌源として果して唯一無二のものであるか否か，さ らに，此れと関連して肝での estrogen 代謝の問題を検討する目的で，以下の様な実験を行つた.

\section{1) 卵菓, 副腎全剔術後の尿中 estrogen}

症例は未期或いは再発乳癌患者で, 本院第二外科に於いて卵紧及び副腎全剔術を行つた13例の婦人を対象 とした. 測定成績は, Fig.10,11,12に示す如くで, 卵絊, 副腎全剔後の尿中 total estrogen 值は急激に著 しく減少し，3 分劃のいずれも低值を示してをり，全例の total estrogen の平均值は $3.7 \mathrm{ug} / 24$ 時間尿であ つた. てれを去勢後の尿中 total estrogen 值と比較すると, 前者の值は後者の約 $1 / 2$ に相当して居る. 又, 術後1〜2ケ月の間では，去勢時と異つて，尿中 estrogen 值の恢復傾向は全く認められず，試みに，ACTH$\mathrm{Z}$ を 3 日間に60単位投与した症例でも, estrogen 值の有意の増加を見なかつた.

\section{2) 卵巣剔出，一側副腎剔出，他側副腎静脈亡脾静脈吻合術後の尿中 estrogen}

肝に於ける estrogen の不活化を目的として, 卵栄剔出及び右側副腎剔出, 左側副腎静脈と脾静脈との吻 合術を併せ行つた乳癌婦人の尿中 estrogen 值を測定した. 其の成績は，Fig. 13,14に示す様に, 術後の尿中 estrogen 值の減少度は, 前述の全剔例に比較すると, 明かに緩徐であり, 吻合術後, ほぼ, 全剔例の尿中 
Fig. 10. Effect of castration \& total adrenalectomy on levels of urinary estrogens

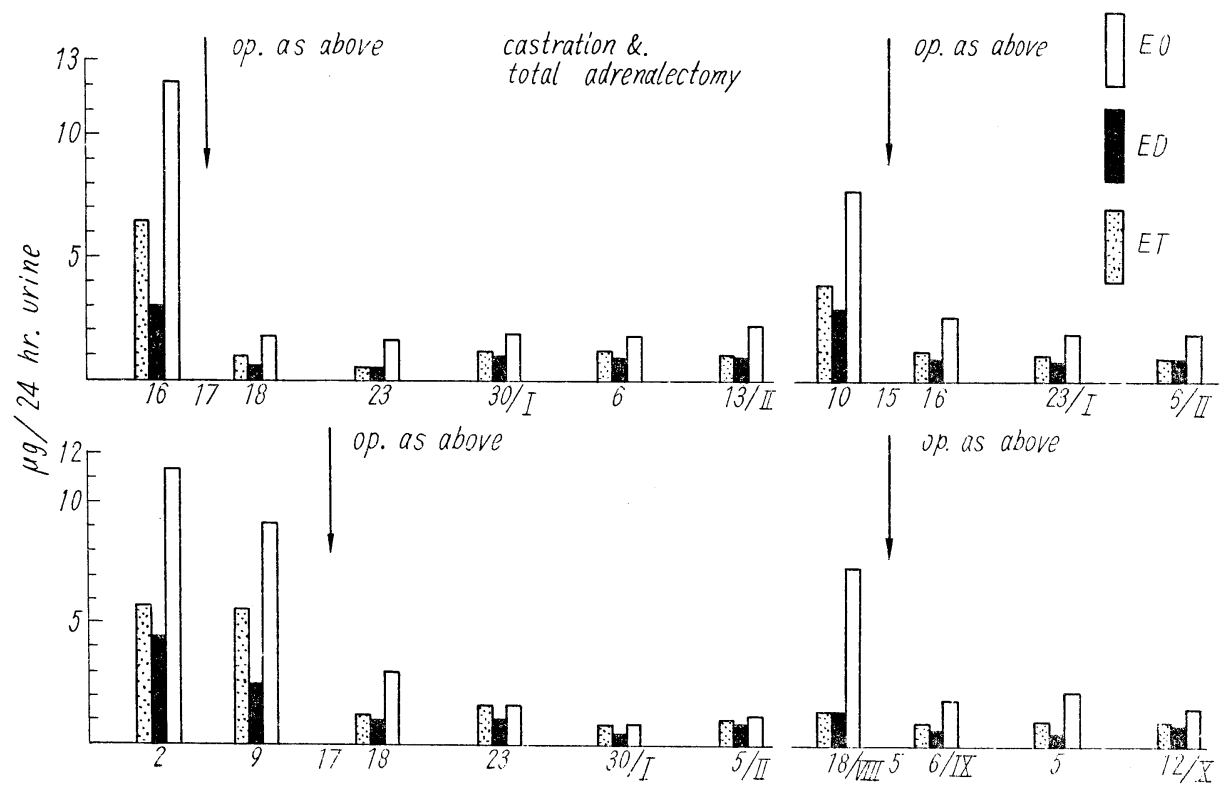

Fig. 11. Effect of ACTH, or norethindrone administration on levels of urinary estrogens after castration \& total adrenalectomy
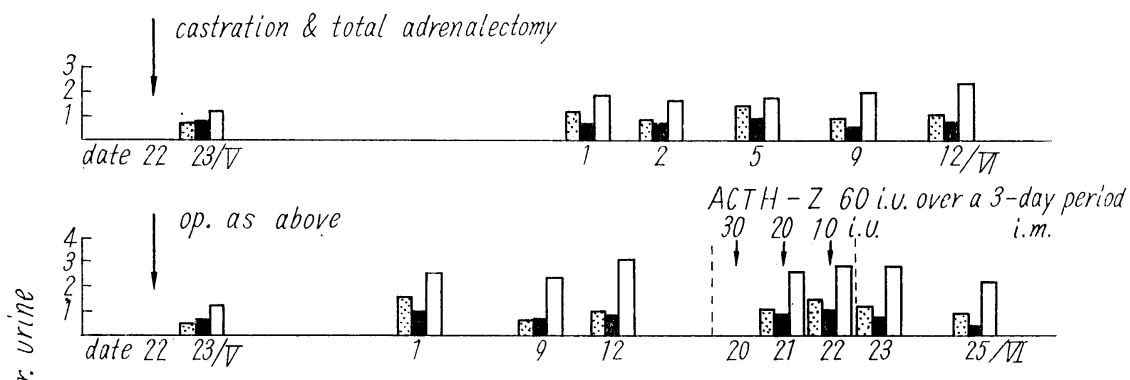

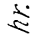

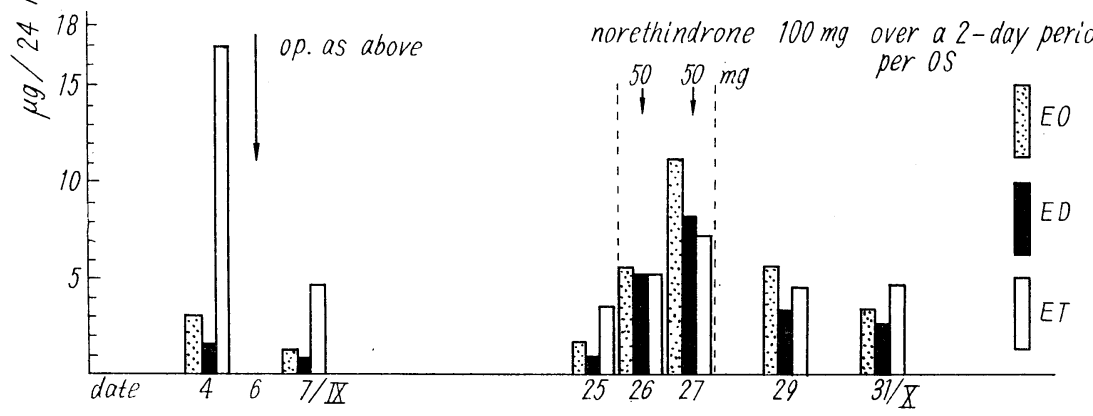

第39巻 第 8 号 
Fig.12. Comparison between the two groups on mean value of urinary estrogens

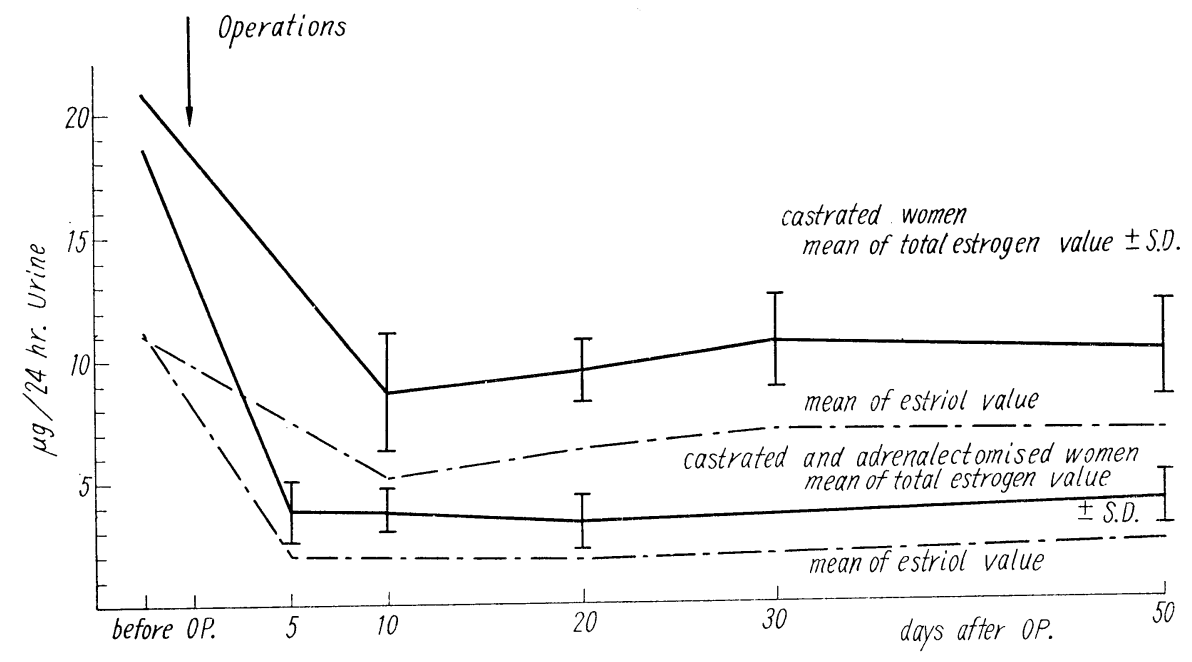

Fig. 13. Effect of operation as below on levels of urinary estrogenes

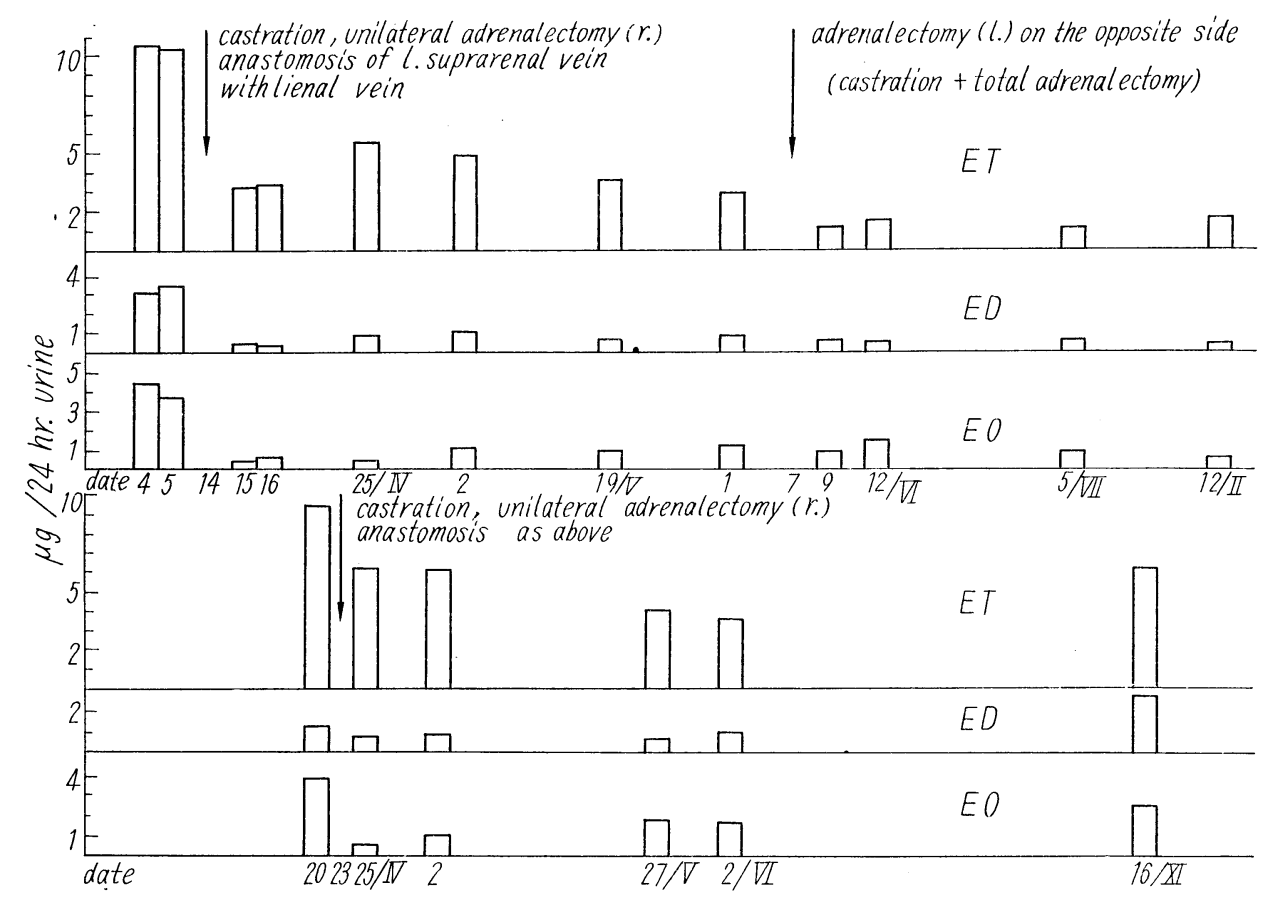


Fig. 14. Comparison between the two cases on the output of urinary estrogens to ACTH administration

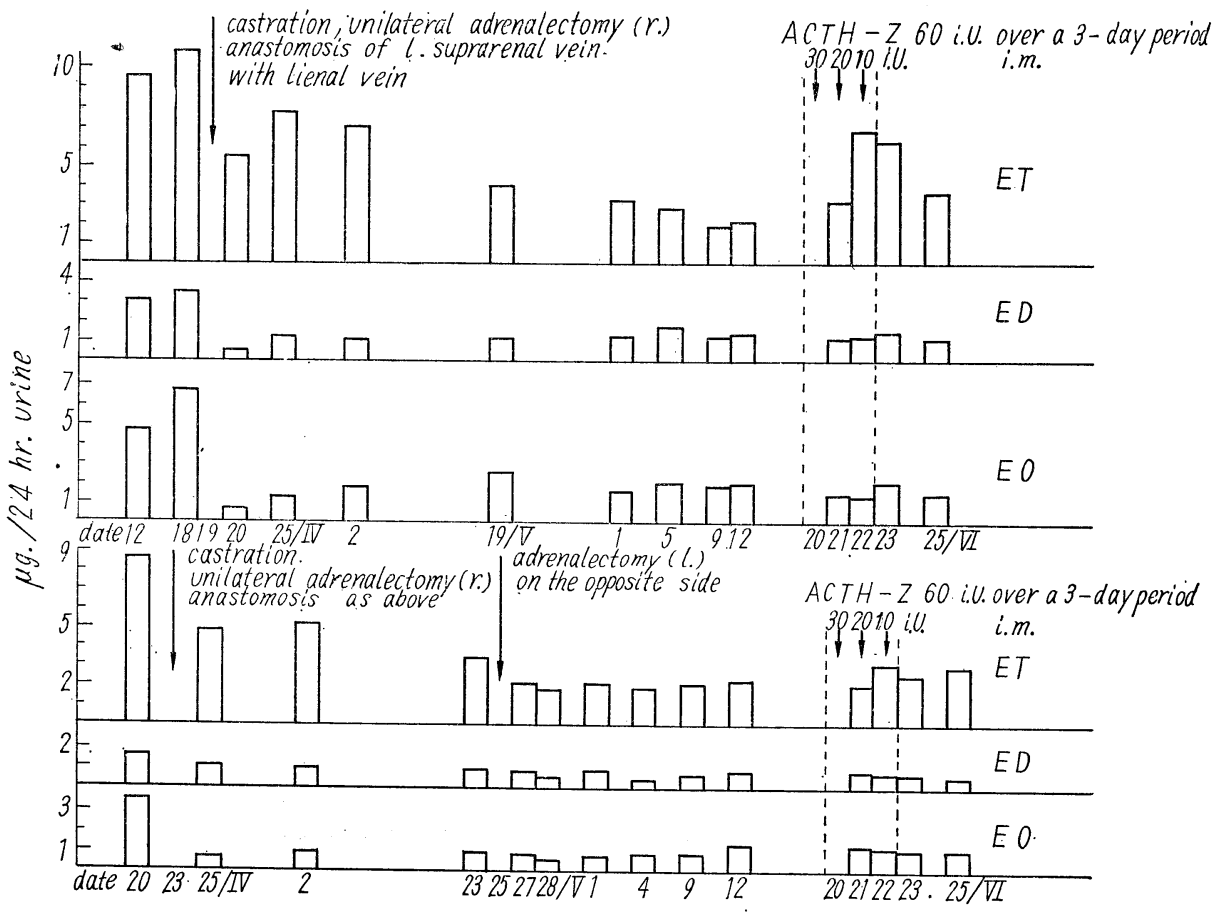

estrogen level 迄に減少するのに約 1 ケ月の期間を必要とする事が判明した，又，本例に ACTH 負荷を 試みた所，全剔例と異つて，尿中 total estrogen 值，殊に， estriol の明かな増加が認められた。

尚, 吻合術後に全剔術を重ねて行つた症例では, 其の estrogen 值は, 各々, 吻合例, 全剔例の所見と一 致して推移を示した.

\section{第五項 副腎剔出婦人の場合}

症例は 2 例の乳癌患者であるが，既に閉経後約10年を経過していたので，卵巣性 estrogen の分泌は停止 して居ると考え, 両側副腎剔出のみ行つて治療効果を観察した例である。此の成績は，Fig.15に示す様に， 2 例共，副腎全剔後，尿中 total estrogen 值は急速に低下し，術前值の約 $1 / 2$ 程度と成つたが，依然，副腎， 卵巣全剔時よりは高い值が保たれ，其の分劃比はほぼ１亿近い值を示して居た。同時に estrogen 值の恢復 傾向が幾分䙼はれて居る。しかし，本例はいづれも其の治療効果が卵巣副腎全剔例に比し不良であつたため 副腎全剔後, 夫々 16 万至 22 日目に, 両側卵单を追加剔除した. この結果, 卵巣剔除後の尿中 estrogen 值は 更に減少し，卵巣副腎全剔例と同じ estrogen level にまで低下した。よつて以上の成績は閉経後の卵巣か らも，尚微量の estrogen を分泌する事を意味すると考觉られる。

しかし，此の反面本例に於いては metabolic estrogen の急墜と言う特殊な事態に対処する生体の調節機 序の一つの現れとも解されるので, 速断する事は慎みたい.

尚次に Cushing 氏病のため入院加療中の年令23才の未婚婦人の尿中 estrogen 值の測定を行つたので, 此の成績を前二者と比較して見た。

症例は約 1 年前より月経不順, 過少月経を自覚すると共に, 急激に肥㭌し, 約半年前より全く無月経と成 り, 症状の悪化を訴えて始めて当院を訪れたものである. 本例は一側副腎剔出, 他側副腎 $3 / 5$ 剔出が行なは れたが，術前，術後の尿中 estrogen 值の推移はFig.16に示す如くである。即ち，術前値は著しく低值を示 
Fig. 15. Effect of total adrenalectomy and later successive castration on levels of urinary estrogens

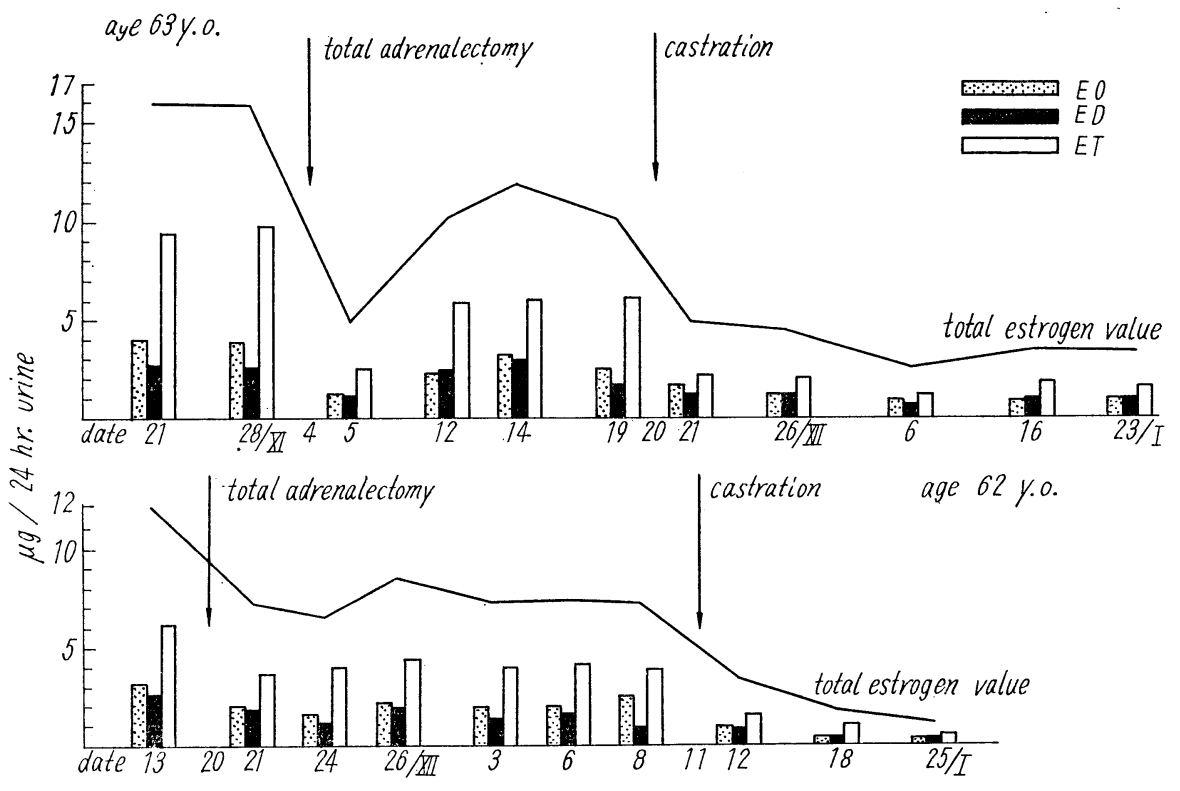

Fig. 16. Effect of subtotal adrenalectomy for Cushing disease on levels of urinary estrogens

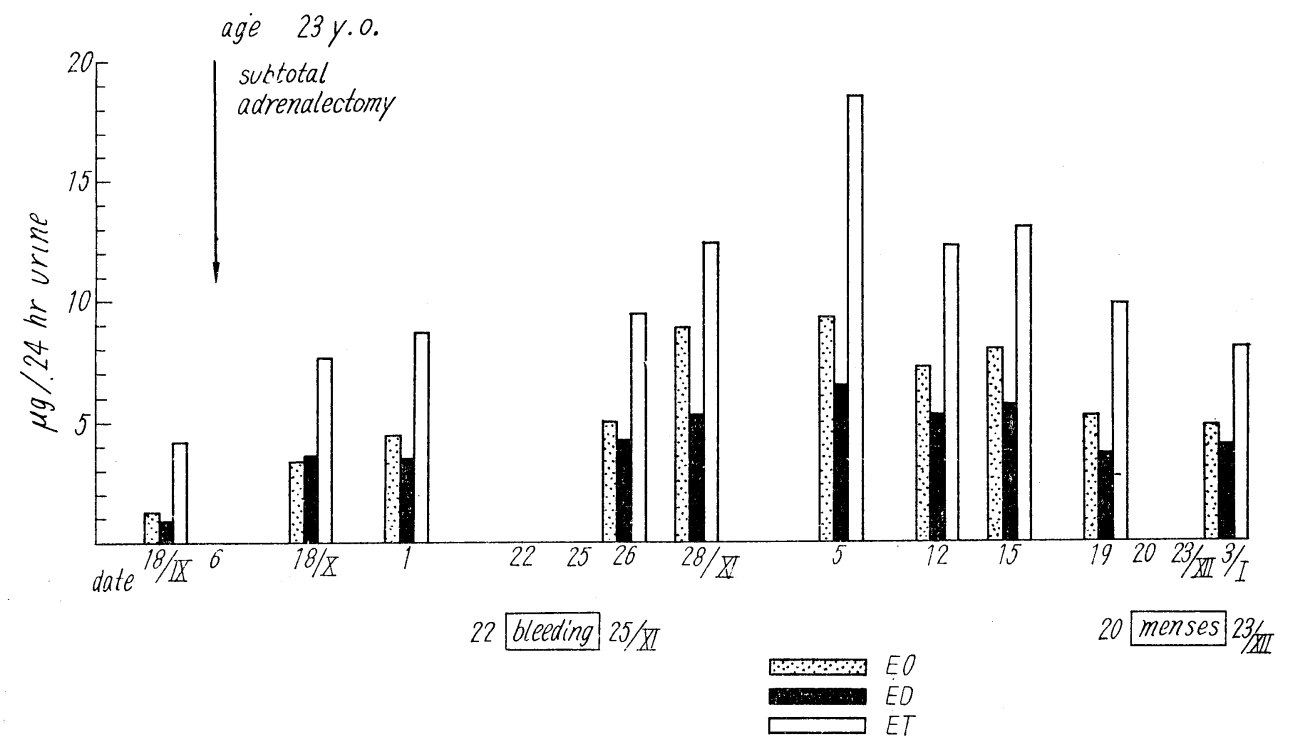


したが，術後日数の経過と共に次第に estrogen 値の増加が見られ，始めて術後47日目より 4 日間性器出血 を見た．其れ以後の尿中 estrogen 值は，更に上昇し，殆んど正常月経周期に見られると同様の pattern を 示し，前回の性器出血第 1 日より数へて第14日目には排卵を思はせる鋭い peak を作り，其の直後 BBT は 上昇して高温相と成り典型的な二相性を示すに至つた。袞体開花期に相当して estrogen 值は高値となり， 次いで下降すると共に第29日目より4 日間, 排卵性月経の発来を見た。以後は整調な排卵性月経を反復して 居る。

\section{第四章 総括並びに考按}

去勢婦人の尿中 estrogen 值の変動を長期間観察した結果， estrogen は去勢直後急速に減少するが，その 後或る程度恢復する事が判明した。また total estrogen 值と 3 分劃中の estriol 值との変動はほぼ平行性が あり, estriol/estrone+estradiol 分劃比が増大する事から, total estrogen 值の恢復は主として estriol 分 劃の恢復に依ると結論した。去勢後のかかる尿中 estrogen 值の減少に就いては Bioassay に依る多くの測 定結果とも一致し, 又 chemoassay を行つた Diczfalusy et al ${ }^{14)}$ (1956), Strong et al ${ }^{5)}$ (1956), Bulbrook ct al $^{6)}$ (1957), Birke et al ${ }^{7)}$ (1958), Brown et al ${ }^{18): 9)}$ (1959), 永田 ${ }^{20)}$ (1960), 高山 ${ }^{2}$ ) (1960) 等も著る しい estrogen 值の減少や少くとも全般に低值を示すと報じて居る．此れに対し Persson，Risholm ${ }^{22}$ (1961) は閉経前や閉経後の乳癌患者に於いて去勢後8～10日間までの尿中 estrogen 值を測定しても，去勢前後の 測定值に著るしい差異を認めないので，此れは恐らく estrogen の enterohepatic circulation の持続に依る ものか，或いは postoperative stress の作用に依るものであろうと説明して居る. 次去勢後の尿中 estrogen の 3 分劃比の変動を比較して見ると，著者の成績では Diczfalusy et $\mathrm{al}^{2} ）$ (1949) が報告した様な分劃 比 $(\mathrm{ET} / \mathrm{EO}+\mathrm{ED})$ の減少は認められず寧ろ estriol の相対的な増加を認めた。此の結果は去勢㷌人に就い ての Brown et al ${ }^{19}$ (1959) の測定成績や Bulbrook ${ }^{24)}$ (1957), Brown ${ }^{25)}$ (1958) の正常閉経期婦人に就いて の成績と同傾向であり, 又乳癌患者で irradiation menopause から長期間経た婦人の尿中 estrogen の測定 を行つた Brown ${ }^{19)}$ の報告とも一致する.

次に，性腺外 estrogen に対する gonadotropin, AGTH 投与の影響に就いて観察したが，著者の用いた 投与量では PMS, HCG は共に去勢後の尿中 estrogen 值に有意の変動を来さない事が判明した。此の結 果は Gemzell, Diczfalusy26) (1959), Bayer, Brever, Nocke ${ }^{27)}(1957,1960)$ ，徳山 ${ }^{28)}$ (1955)，松浦 ${ }^{29}$ (1958) 等の報告と一致するものである. gonadotropin の投与実験に於いて estrogen 值の增加を認めたと言う報 告もあるが，市販の gonadotropin 製剤は屡々 ACTH の contamination が認められるので，其の判定は 慎重に行はれるべきであろう。

去勢動物に於いて，副婜皮質の肥大，発情期の異常持続や皮質の腫疸性增殖の惹起される事を Dorfmann (1944), Frantz (1949) が報告し, Stieve ${ }^{54}$ (1947), Wense ${ }^{55}$ （1958）等はようやく人に於いて，卵巣性 estrogen の分泌停止や減少が代償的と解される副腎皮質束状層の hyperplasia を惹き起す事を組織学的に 証明したが，皮質に於ける estrogen の生成は縓密な localisation がなく，其の生成の証明すら不完全であ る。しかし乍ら, 著者の実験成績からはやはり性腺外 estrogen を主に control する上位 hormone はACTH であると考えねばならない.

また著者は corticoid の投与を行つて見たが其の結果は予期した通り，尿中 total estrogen 值の減少，

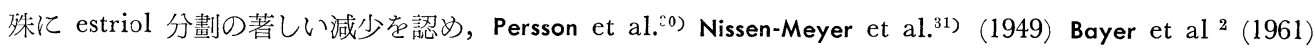
の成績とほぼ一致する事を知つた。

次に合成 gestagen 剤 norethindrone の投与が去勢婦人の尿中 estrogen に及ぼす影響に就いて観察した が，其の結果は前述の様に，少量投与時には尿中 estrogen の 3 分劃中殊に estriol が減少し， corticoid と 同様に副腎皮質に対し抑制的に働く様に見えた，此の成續は教室の野喜の去勢婦人に norethindrone を投 与すると pregnanetriol 值の著るしい減少を見たと言う成績や Fortherby $\left.{ }^{33}\right) の$ pregnanetriol の precusor である $17 \alpha$-hydroxyprogesterone が estrogen の生合成に一部関与すると言う最近の報告と対比して可成り 
興味深い. 且し此の機序に就いては不明であり, 唯 Huis int Veld \& Van der Spek“4) (1958) は 19-nor.の 投与は 17-KS, 17-OHCS の排泄值を低下させ，しかも此れが副腎皮質に対する本剤の直接的な作用に依る ものであると述へて居る。一方, norethindrone の大量投与時には主に estrone, 次いで estradiol 分劃の 增加を認めたが，此の成績は Kaiser ${ }^{5)}$ (1957), Brever et al ${ }^{6)}$ (1960) の報告と一致し, estrogen の conversion の可能性を示して居り, 又本剤の投与が臨床的にも breast engorgement や climacteric symptoms の緩和をもたらすと言う Paulsen ${ }^{37}$ （1962）等の報告を支持する成績を得た。著者は更に本剂を卵巣副腎全 剔例にも投与して全く同一の結果を得た.

此の様な所謂 steroid conversion は他の 19-norsteroids や dehydroepiandrosterone, testosterone 等を 生体に投与した実験でも明かにされて居り, 従つて卵巣性 estrogen の分泌の停止後や去勢後では尿中 estrogen の大部分が副腎皮質に由来するとは言元, extraglandular に androgen 等の neutral steroids 加ら も estrogen が生成され得る可能性のあるてとを忘れてはならない.

次に, 乳癌患者に行なはれた卵巣, 副腎全剔術後の尿中 estrogen 值の測定結果は結論的に言つて, 性腺 外 estrogen の大部分がやはり副腎皮質に由来する事を裏付けたと言えるが，此の成績は Strong et al ${ }^{i j}$ (1956), Bulbrook et al ${ }^{\text {s) }}$ (1960), 永井 ${ }^{9)}$ (1960) 等の報告とほぼ同一であり, 中でも Brown ${ }^{19}$ (1959) の報 告した値に最も近似して居る, そして去勢後に見られた尿中 estrogen 值の恢復傾向や ACTH 投与に依る 増加は此の場合認められない. また本手術後に於いても尿中 estrogen 值が 0 にはならないと言うことは興 味ある知見であり, Bulbrook ${ }^{8)}$ (1960) も此れを生物学的に実証して居る. そてで此の分泌源として(1) 補副 腎の形式, (2) Steroidhormon 特に術後の副腎不全防止に投与せられた cortisone からの conversion, (3)食 餌性 estrogen の摂取等が推定されて居るが此の点に就いての解決は将来に待たねばならない，唯，Chang et $\mathrm{al}^{40)}$ (1961) は 4-C:4cortisone acetate が0.07\%の割合で estrogen に conversion される事を証明して いる.

次に乳癌患者で卵巣, 右側副腎を剔出し, 左側副腎静脈と脾静脈の吻合を行つて, 其の静脈血を門脈系に 還流させた症例の尿中 estrogen を測定したが，此の場合全剔例に比し，術後の尿中 estrogen の減少度は， より緩徐であつた，又全剔例及び吻合例に夫々 ACTH 負荷を行つたが，全剔例では尿中 estrogen 值の増 加を認めないのに反し, 吻合例では肝の不活性化作用に依つて可成り減少して居た尿中 estrogen がー過性 に明が増加し，overflow phenomenon とも解されるべき所見を得た。吻合例の尿中 estrogen 值に就い て検討した研究は少ないが，永井 ${ }^{9}$ (1960) は total estrogen 值から見て50\%の減少率を見たと報告し, Galante et $\left.\mathrm{al}^{4}\right)$ (1955) は吻合例䎲 ACTH を投与すると, 生物学的測定成績から見て, 尿中 estrogen 值 は減少しなかつたと述べて居る。

又肝の estrogen 代㴬に極めて重要な役割を果す enterohepatic circulation の存在を初めて証明した Cantarow et al ${ }^{42)}$ (1942) の研究に依ると肝に於ける estrogen molecule の分解は従来の in vitro の成績 に反し，生体内では緩かであるとし，Twombly et al ${ }^{4}$ ) (1950) も radioactive bromestrone を用いて同様 の結果を人体に於いて得て居るのは䁬知の通りである.

さて，以上の成績を概観すると，Meyer ${ }^{44)}$ (1955) 等の副腎皮質組織存在下に於ける 19-hydroxyandrostendione からの estrogen 生合成に就いての報告, 或いは副整静脈血中の estrogen 濃度は末梢静脈血中の

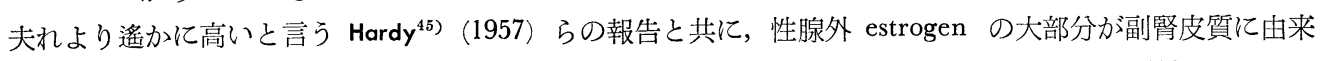
する事を示して居る，其れでは此のものが果して如何なる型で副腎皮質より分泌されるか，即ち estrogen そのものの型としてか，それとも前駆物質として estrogen の生合成にあづかるかは甚だ興味ある問題であ る. 今もし，此れが estrogen として分泌されるのであれば，此の大部分は生体内で estriol 亿代謝され， 尿中に排泄せられなければならない，尿中 estrogen と生体内で産生された estrogen との関係を検べた Brown $^{46)}$ (1957) の実験成績に依ると，投与 estrone の約 $46 \%$ が又 estradiol-17 $の$ の場合は約 $44 \%$ が estriol に代謝されて尿中に排泄されるに過ぎないのであるから，副腎皮質より estrone，estradiol-17 $\beta$ が分泌され て居るとすれば，前記の ACTH 投与時に見られた様に，尿中 estrogen 值の増加の約70〜90\%が estriol 
で占められる事実と一致しない事に成る，又 estriol 投与時は100\% estriol の型で直ちに排泄される事が知 られて居るが，もし estriol として皮質より分泌されるとすれば，前記の如く AGTH の投与に依つて尿中 の estriol が estrone, estradiol の増加より1 日遅れて最大值に達する様な事はない. 何故ならば此の 1 日 の遅れは estriol の排泄に時間を要したためではなく, estriol への代謝に時間を要するためである事がすで に確められて居るからである。従つて此の場合, estrone や estradiol-17 $\beta$ でなく, 高率に estriol 亿代謝さ れ得る estrogen の存在の可能性も予想される次第である. 更に estrogen の前駆物質として分泌せられると すれば，此のものは前記した様に estrogen 光高率に conversion され易い化合物として分泌されるのであ ろう。しかし，現在迄に副婜皮質組織中に存在し，estrogen に転換される事が知られて居る Androst-4-en,3, 17-dion, Dehydroepiandrosteron 等の estrogen 光の conversion rate は, 生体内に於いては僅か $1 \%$ 以 下に過ぎず，従つて現在の見解では此等の neutral steroids の果す役割は性腺外 estrogen の極く一部を占 めるにすぎないと言わなければならない。

次に前記の副腎剔出例に就いての測定成績から，閉経後の卵巣も尚微量の estrogen を分泌する可能性の あるととが推定されたが，Paulsen et $\mathrm{al}^{47}$ ) (1958) は閉経後1〜2年を経過しても卵巣は依然 gonadotropin の投与に依つて反応し，尿中 estrogen の增加を見たと報し，一方 Gemzell et al ${ }^{26)}$ (1959) は卵策に於ける follicle の消滅後は FSH に反応しない事を報告した，Hordy et al ${ }^{45}$ ) (1957) も40才以下と40才以上（平均 年令 57 才）の 2 群の婦人の卵巣静脈の血中 estrogen 值を測定し, 後者に於いても尚前者の約 $1 / 3$ に相当する estrogen 分泌能が維持されて居ると述べて居る. Heller and Heller ${ }^{48}$ (1944) は更年期後に於ける卵巣剔除 が所謂 vegetative instability を強める事から此の時期に於いても卵巣は依然重要な estrogen 分泌源であ ろうと考え，Hertig ${ }^{49)}$ (1944) は閉経後の卵巣は其の間質細胞が estrogen を分泌すると述べて居るが本邦の 松本 ${ }^{50)}$ (1962) も閉経と同時に卵巣機能が全く停止するのでは無く多少の内分泌活動があると報告して居る. 上述の報文を綜合すると，著者の成績も被検者の年令よりして人に於ける卵巣間質細胞の estrogen 分泌能 を示すものではなからうかと考えられる。

最後に著者は Cushing disease と診断された $21 才 の$ 婦人の副腎亜全剔出前後の尿中 estrogen 值の変動を 検べたが，極めて興味あるものであつた．Frank ${ }^{5 .)}$ (1933) は副腎の benign hyperplasia や adenomaの場 合 estrogen 值は通常低值であると述べ，又 Diczfalusy ${ }^{52}$ (1961) は estrogen 生成能のある adrenocortical tumor は比較的稀であるとして居る．本例の術前の gonadotropin 值は正常で, 17-OHCS 值は著しい高値 を示したが，17KS值はやや増加した程度であり，身体所見として者しい肥㭌の他男性化兆候は認められな かつた。 さて androgen 過剩型の無排卵性月経異常に対し cortisone, dexamethasone 投与が有効である 事は一般に認められて居るが，Seelen et $\mathrm{al}^{5}$ ’（1960）も報告する様に adrenocortical dysfunction の所見

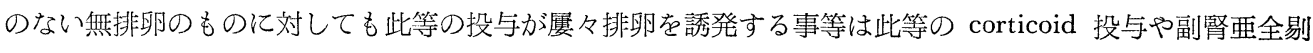
との間に排卵に関して共通の機序が存在し，恐らく副腎皮質機能の正常化乃至は抑制が或種の corticoids の 過剩分泌を低下させる事に依つて直接的或いは間接的に卵巣機能を賦活するのであろうと想像させる.

性腺外 estrogen との関連の未だ漢然とした臨床上の多くの知見を人での正確な hormone assayに依つ て検討する必要から，上述の如き実験を行つたが今後卵巣と副腎皮質の機能的関連に就いて下垂体をも含め て更に慎重に検討を進めたい.

稿を終るに臨み，御愁篤な御指導御校閲を戴いた植田教授に樑く謝意を表すると共に，御助言，御支援下 さつた林講師及び貴重な実験の機会を与えられた第 2 外科石川教授, 長谷川講師, 津田博士荧始凶便宜を計 つて下さつた協同研究者に深謝します。

\section{文献}

1) CALLOW, N.H. et al : Biochem. J., $34: 276$, (1940).

2) BEALL, D. : Biochem. J., 34 : 1293, (1940).

3) HUGGINS, C., et al : J.A.M.A., $147: 101$, (1951).

4) ITTRICH, G. : 
Hoppe-Seylers Z. physiol. Chem. : 312 : 1, (1958).

5) ITTRICH, G. : Zbl. f. Gynäk., 7 : 255, (1959).

6) ITTRIGH, G. : Zbl. f Gynäk., $11: 429$, (1960).

7) ITTRIGH, G. : Acta endocrinol., $35: 34$, (1960).

8) SALOKANGAS, R.A.A., et al : J. Endocrinol., 22 : 47, (1961). 9) BROWN, J.B. : Biochem. J., $60: 185$, (1955). $\quad$ 10) BROWN, J.B. et al : J. Endocrinol., 16 : 49, (1957).

11) COHEN, H. et al : J. Chem. Soc., $6: 653$, (1934).

12) HEARD, R.D.H. et al : J.B.C., $141: 709$, (1941).

13) STIMMEL, B.F. : J.B.C., $162: 99$, (1946).

DICZFALUSY, E. et al : Acta endocrinol., $21: 321$, (1956). $\quad 15)$ STRONG, J.A. et al : Lancet, $2: 955,(1956)$ 16) BULBROOK, R.D. et al : Acta endocrinol. Suppl., $31: 324$, (1957).

BIRKE, G. et al : Acta endocrinol., $29: 55$, (1958). 18) BROWN, J.B. et al : J. Obstet. Gynaec. Brit. Emp., $66: 177$, (1959). 19) BROWN, J.B. et al : J. Endocrinol., $19: 52$, (1959).

20)

永田 : 神戸医大紀要, $21: 154,(1960)$,

21) 高山：日産婦誌, $12: 1015,(1960)$.

22) PERSSON, B.H. et al : Gited from Diczfalusy, G. edited “Oestrogene beim Menschen." (1961). 23) DICZFALUSY, E. et al : J. Glin. Endocinol \& Met., $19: 1230$, (1959).

24) BULBROOK, R. D. : Gited from "Oestrogene beim Menschen,, Brit. Med. J., 1 : 662, (1957).

25) BROWN, J. B. : Gited from "Oestrogene beim Menschen," 26) GEMZELL, G.A. et al : Acta obst. et Gynec. Scand., $38: 465$, (1959). 27) BAYER, J.M. et al : Gited from Endocrinologie, $40: 9$, (1961). 28）徳山：日内分泌誌，31：549，(1955). 29) 松浦：日内分泌諗，34：190，(1958). PERSSON, B.H. et al : Gited from "Oestrogen beim Menschen" 31) NISSEN-MEYER, R. et ol : ibid. 32) BAYER, J.M. et al : Endokrinologie, $40: 9$, (1961).

33) FORTHERBY, K. : J. Endocrinol., $25: 19$, (1962). $\quad 34)$ HUIS IN'T VELD., et al : Acta endocrinol., $33: 388$, (1960). 35) KAISER, R. et al : Arch f Gynäk., 194: 146, (1960). 36) BREUER, H. et al : Acta endocrinol., $33: 10,(1960)$ 37) PAULSEN, C.A. et al : J. Glin. Endocrinol \& Met., 22 : 1033, (1962). 38) BULBROOK, R.D. et al : J. Endocrinol., $20: 220$, (1960). 39) 永井：日外会誌, $61: 1021,(1960)$. 40) CHANG, E. et al : J. Endocrinol., $21: 624,(1961)$. 41) GALANTE, M. et al : Surg. Forum., $5: 667$, (1955). 42) CANTAROW, A.et al : Endocrinol., $31: 515,(1942)$ 43) TWOMBIY, G.H. et al : Cancer, $3: 601$, (1950). 44) MEYER, A.S. : Cited from "Oestrogene beim Nenschen,, 45) HARDY, J.D. et al : Surg. Forum., 9 : 109, (1957). $\quad 46)$ BROWN, J.B. : J. Endocrinol., $16: 202,(1957) . \quad$ 47) PAULSEN, G.A., et al : J. Amer. Geriat. Soc., $6: 803$, (1958). 48) HELLER, G.G. et al : J. Clin. Endocrinol., $4: 101,(1944)$ 49) HERTIG, A.T. : J. Clin. Endocrinol., $4: 581,(1944)$. 50) 松本 : 日産婦宿題報告要旨，(1962)。 51) FRANK, R.T. : Cited from “Oestrogene beim Menschen. 52) DICZFALUSY, E. : ibid 53) SEELEN, J.G. et al : Acta endocrinol., $34: 189$, (1960). 54) STIEVE, H. : Z. Geburtsh. Gynäk, $127: 209$, (1947). $\quad$ 55) WENSE, Th. VON et al : Cited from Diczfalusy, G. edited “Oestrogene beim Menschen” (1961). 